\title{
Effect of different variants of filler metal S Ni 6625 on properties and microstructure by additive layer manufactured using CMT process
}

\author{
Manuela Zinke $^{1}$ (D) Stefan Burger ${ }^{1} \cdot$ Julius Arnhold $^{1} \cdot$ Sven Jüttner ${ }^{1}$ \\ Received: 27 October 2020 / Accepted: 2 March 2021 / Published online: 8 April 2021 \\ (C) The Author(s) 2021
}

\begin{abstract}
The influence of arc energy and different filler metal composition on the mechanical properties and macro- and microstructure of additively welded thin-walled structures of Ni-based alloy were investigated using four different variants commercially available solid wire electrodes of type S Ni 6625. As the welding process, the Cold Metal Transfer (CMT) process was used. The heat input and cooling rate were varied by adjusting wire feed and travel speed. The results show that an increase in arc energy leads to longer $t_{10 / 6}$ cooling times. This leads to an increase in the dendrite arm spacing and thus to a reduction in the strength values and hardness of the thin-walled structures. The higher Fe-containing variant of S Ni 6625 produces the highest strength and hardness values, while the $\mathrm{W}$-alloyed solid wire electrode produces the lowest values. The porosity in the walled structures was very low, and unacceptable weld defects, hot cracks and lack of fusion did not occur. Segregations occur in all weld metal specimens. While niobium, molybdenum and titanium are the preferred segregations in the Nb-alloyed Ni 6625 type weld metal, only Mo is present in the W-alloyed Ni 6660 type weld metal.
\end{abstract}

Keywords Ni-base alloys $\cdot$ Additive manufacturing $\cdot$ CMT $\cdot$ Thermal cycles $\cdot$ Mechanical properties $\cdot$ Secondary phases $\cdot$ Primary dendrite arm spacing

\section{Introduction}

Alloy 625 (NiCr22Mo9Nb, material no. 2.4856) is a nickelchromium-molybdenum-niobium alloy, which has excellent corrosion resistance to a wide range of corrosive media. As the alloy was already developed and patented at the end of the 50 s [1], a great deal of experience is available regarding the weldability and welding possibilities of this alloy. The alloy is used for both joint welding and cladding of carbon steels in a wide range of industrial sectors, such as aeronautical, aerospace, chemical, petrochemical and marine industries [2,3]. The semi-finished products of Alloy 625 are manufactured in two grades of different heat-treated conditions. Grade $1(\mathrm{C} \leq$

Recommended for publication by Commission II - Arc Welding and Filler Metals

Manuela Zinke

manuela.zinke@ovgu.de

1 Institute of Materials and Joining Technology, Otto von Guericke University, Magdeburg, Germany
$0.03 \mathrm{wt} \%$ and annealed at $950-1050{ }^{\circ} \mathrm{C}$ ) is normally applied for wet corrosion applications and service temperatures up to $600{ }^{\circ} \mathrm{C}$. In contrast, grade $2(\mathrm{C} \leq 0.10 \mathrm{wt} \%$ and solution annealed at $1080-1160^{\circ} \mathrm{C}$ ) is employed for high-temperature applications and at service temperatures above $600{ }^{\circ} \mathrm{C}$ [4]. The similar solid wire electrode $\mathrm{S}$ Ni 6625 with a $\mathrm{C}$ content of max. $0.10 \mathrm{wt} \%$ and max. $5.0 \mathrm{wt} \% \mathrm{Fe}$ is available for both variants (see Table 1).

In the past, however, the Fe content of the filler metal has been steadily reduced to below $1.0 \mathrm{wt} \%$, as it is mainly used for cladding [7], although customer specifications often only require Fe limits of $5 \mathrm{wt} \%$.

Since this material is used in a wide range of industrial applications, it is also of great interest for additive manufacturing. As is well known, additive manufacturing with wirebased arc processes offers the possibility of producing small and large-volume components of low and medium complexity at high assembly rates. A disadvantage is the poorer surface quality and accuracy and thus the need for mechanical finishing of functional surfaces $[8,9]$. In a survey conducted by various German companies, the most important requirement for additive welding was the guarantee of the property 
Table 1 Nominal chemical composition (wt \%) of filler metals and substrate plate $[5,6]$

\begin{tabular}{lcccccccccccccc}
\hline Alloy designation material no. & Product & $\mathrm{C}$ & $\mathrm{Mn}$ & $\mathrm{Si}$ & $\mathrm{Cr}$ & $\mathrm{Mo}$ & $\mathrm{Fe}$ & $\mathrm{W}$ & $\mathrm{Cu}$ & $\mathrm{Ni}$ & $\mathrm{Al}$ & $\mathrm{Ti}$ & $\mathrm{Nb}(+\mathrm{Ta})$ \\
\hline S Ni 6625 2.4831 & Solid wire & $\leq 0.10$ & $\leq 0.5$ & $\leq 0.5$ & $20-23$ & $8-10$ & $\leq 5$ & - & $\leq 0.5$ & $\geq 58$ & $\leq 0.4$ & $\leq 0.4$ & $3.0-4.1$ \\
S Ni 6660 --- & Solid wire & $\leq 0.03$ & $\leq 0.5$ & $\leq 0.5$ & $21-23$ & $9-11$ & $\leq 2$ & $2-4$ & $\leq 0.3$ & $\geq 58$ & $\leq 0.4$ & $\leq 0.4$ & $\leq 0.2$ \\
NiCr22Mo9Nb 2.4856 & Plate & $\leq 0.10$ & $\leq 0.5$ & $\leq 0.5$ & $20-23$ & $8-10$ & $\leq 5$ & - & $\leq 0.5$ & $\geq 58$ & $\leq 0.4$ & $\leq 0.4$ & $3.15-4.15$ \\
\hline
\end{tabular}

profile of the manufactured components according to the operating stresses, followed by process time, component volume, dimensional accuracy and rework. This property profile depends strongly on the material and welding regime [10].

Direct energy deposition processes with arc (DED-arc) for additive layer manufacturing (ALM) with Ni-based solid wires is typically performed by plasma arc welding (PAW), tungsten arc welding (GTAW) and gas metal arc welding (GMAW) processes. The cold metal transfer (CMT) process is a variant of GMAW, which are widely used industrially for cladding with S Ni 6625 [2,11-13]. This is due to the very low dilution with substrate, high deposition rate, very low heat input, less spatter and low susceptibility to hot cracking [14]. Factors are also advantageous for the ALM.

The focus of investigations on Alloy 625 during the manufacture of different structures (thin wall square, round, konus and compact block) in as-deposited and heat-treated conditions is the influence of the process technology mentioned and the associated heat input on macro- and microstructure, formation of intermetallic phases (e.g., Laves phase) and seam irregularities (e.g., hot cracks and pores) and mechanical properties (tensile test by room temperature, hardness) in travel or build direction [15-22]. Current studies are concerned also with the influence of the additive generated microstructure on corrosion resistance $[23,24]$. It was also shown that the presence of Laves and other intermetallic phases in the Inconel 625 deposit accelerated the localised corrosion rate and pitting corrosion under high-temperature and highpressure (HTHP) $\mathrm{H}_{2} \mathrm{~S} / \mathrm{CO}_{2}$ conditions [23]. Table 2 summarises the results with respect to the mechanical properties of the ALM structures at room temperature in the as-deposited state of alloy 625. Similar to cladding with Alloy 625, strong accumulations of the elements $\mathrm{Nb}$ and $\mathrm{Mo}$ in the interdendritic regions of the weld metal are reported, which promotes the formation of Laves phase and mixed carbides. The morphology and the content of Laves phase depend on the temperature gradient and the cooling rate during solidification [25].

The paper informs about the effects of different energy input on cooling times, seam irregularities, chemical composition, mechanical properties and microstructure CMT welded thin-walled wall structures of wire electrodes of the type $\mathrm{S} \mathrm{Ni}$ 6625 and $\mathrm{S} \mathrm{Ni} 6660$. In addition to the standard variant of this filler metal, the influence of two further variants of S Ni 6625, which have been specially developed for additive manufacturing, is discussed. While one variant has an increased Fe content of approx. $4 \mathrm{wt} \%$, the other variant is said to have a higher degree of purity. In chemical analysis, the welding filler S Ni 6660 is basically similar to the welding filler S Ni 6625. However, here, the element niobium is substituted by tungsten (Table 1).

\section{Experimental procedure}

\subsection{Methods for characterisation of the wire electrodes}

To determine the exact chemical composition, the wire electrodes were melted into buttons with the Arc Melter MAM-1 (Edmund Bühler $\mathrm{GmbH}$ ) in pure argon atmosphere (99.996 $\%$ ) using a TIG arc. The methodology is described in [26]. After mechanical grinding, optical emission spectrometry (OES) on SPECTROLAB (SPECTRO Analytical Instruments $\mathrm{GmbH}$ ) was performed on the buttons. In addition, the contents for oxygen, nitrogen, hydrogen, carbon and sulphur were measured by means of carrier gas melt extraction (CGME) on the G8 GALILEO ONH and on the G4 ICARUS Series 2 (Bruker) directly on the sample material of the wire electrodes in the delivery condition. Afterwards, measurements of the wire diameter, the surface roughness (axial) with the tactile cut method [27], and tensile tests were carried out.

\subsection{Methods for assessment of welding process behaviour and cooling time}

CMT welding was carried out on two different welding stands using the Fronius CMT 4000 Advanced and Fronius TPS 2700 CMT welding power sources with the respective RCU 5000 control unit. Accompanying the welds, the electrical welding parameters, the shielding gas flow and the wire feed speed were recorded. While the sampling rate in the welding power source is fixed at $1 \mathrm{kH}$, the external measuring system WeldAnalyst-S2 (HKS Prozesstechnik GmbH) was used to measure of electrical welding parameters at a sampling rate of max. $25.6 \mathrm{kHz}$. Alloy 625 with dimensions of $250 \mathrm{~mm} \times$ $150 \mathrm{~mm} \times 5$ or $10 \mathrm{~mm}$ (length $\times$ width $\times$ thickness) was used as a substrate sheet. The production of the wall structures was done in a 1-welding bead/layer-technique. The welding direction was changed after each layer (Fig. 1). A mixed gas consisting of $30 \% \mathrm{He}, 2 \% \mathrm{H}_{2}, 0.05 \% \mathrm{CO}_{2}$, and rest $\mathrm{Ar}$ 
Table 2 Comparison of mechanical properties by room temperature of ALM structures of alloy 625 produced by different DED-arc methods

\begin{tabular}{|c|c|c|c|c|c|c|c|}
\hline \multirow[t]{2}{*}{ Process } & \multirow[t]{2}{*}{ Structure } & \multirow[t]{2}{*}{ Type of tensile specimen } & \multicolumn{4}{|c|}{ Tensile properties by RT } & \multirow[t]{2}{*}{ Reported in } \\
\hline & & & Tensile direction in & $\begin{array}{l}\text { UTS } \\
{[\mathrm{MPa}]}\end{array}$ & $0.2 \% \mathrm{YS}[\mathrm{MPa}]$ & $\begin{array}{l}\mathrm{E} \\
{[\%]}\end{array}$ & \\
\hline PPAD & Block & EN 10002-1:2001 & Travel direct. (Y) & 771 & 480 & 50 & $\mathrm{Xu}[15]$ \\
\hline GTAW & Wall & Sub-sized & $\begin{array}{l}\text { Travel direct. (Y) } \\
\text { Build direct. (Z) }\end{array}$ & $\begin{array}{l}722 \pm 17 \\
684 \pm 23\end{array}$ & $\begin{array}{l}- \\
-\end{array}$ & $\begin{array}{l}42.3 \pm 2.4 \\
40.1 \pm 3.7\end{array}$ & Wang [19] \\
\hline CMT & Square wall & Sub-sized ASTM E8 & Build direct. (Z) & $658 \pm 4$ & $373 \pm 5$ & $56 \pm 4$ & Tanvir [21] \\
\hline $\begin{array}{l}\text { CMT } \\
\text { CMT pulse }\end{array}$ & Wall & Sub-sized ASTM E8 & $\begin{array}{l}\text { Build direct. (X-Z) } \\
\text { Build direct. (X-Z) }\end{array}$ & $\begin{array}{l}579 \\
595\end{array}$ & $\begin{array}{l}253 \\
283\end{array}$ & $\begin{array}{l}- \\
-\end{array}$ & Mookara [24] \\
\hline CMT weave bead & Wall & Sub-sized EN 2002-1:2005 & $\begin{array}{l}\text { Build direct. (Z) } \\
\text { Travel direct. (Y) }\end{array}$ & $\begin{array}{c}641 \pm 9.7 \\
693 \pm 12.6\end{array}$ & $\begin{array}{l}- \\
-\end{array}$ & $\begin{array}{l}60 \pm 1.0 \\
49 \pm 2.7\end{array}$ & Jiang [22] \\
\hline CMT 2 bead/layer & & & $\begin{array}{l}\text { Build direct. (Z) } \\
\text { Travel direct. (Y) }\end{array}$ & $\begin{array}{l}683 \pm 11.1 \\
751 \pm 17.6\end{array}$ & $\begin{array}{l}- \\
-\end{array}$ & $\begin{array}{l}59 \pm 1.1 \\
53 \pm 2.3\end{array}$ & \\
\hline
\end{tabular}

was used as shielding gas. There was no brushing between the layers. The contact tip was changed after each bar. To vary the deposition rate and heat input, the wire feed and welding speeds were varied as a function of the wire diameter (see Table 3). The wire feed rate was varied between 6.0, 7.5 and $9.0 \mathrm{~m} / \mathrm{min}$ for $1.2 \mathrm{~mm}$ wire diameter and between 9.0 and $11.0 \mathrm{~mm}$ for $1.0 \mathrm{~mm}$ wire diameter. For each wire feed speed, the welding speed was used between 10,13 and $17 \mathrm{~mm} / \mathrm{s}$ (for $\varnothing 1.2 \mathrm{~mm}$ ) and 7, 10 and $13 \mathrm{~mm} / \mathrm{s}$ (for Ø $1.0 \mathrm{~mm}$ ). The CMT welds were performed in synergic mode with different welding programmes to ensure high arc stability. Both codes ensure this but result in small differences in the arithmetic mean values of current and voltage and consequently of heat input.

During the welding process, non-contact temperature measurements were carried out on selected welds using infrared pyrometers of two different types: the 1-channel IR pyrometer from Micro Epsilon CTLM-2HCF4-C3 (385-1600 $\left.{ }^{\circ} \mathrm{C}\right)$ and the 2-channel IR pyrometer Metis M311/M322 (350-1300 ${ }^{\circ} \mathrm{C}$ ) from Sensotherm. For the 1-channel pyrometer, it was necessary to determine the emissivity for the basic conditions during welding. This was done by comparative measurements of the pyrometer with a type $\mathrm{K}$ thermocouple on a previously manufactured bar of each filler metal. The welded bar was heated with a gas flame and then cooled down. The emissivity was then adjusted until the T-t curves of both measuring devices were almost congruent (see Fig. 2). When using the $\mathrm{S} \mathrm{Ni}$ 6625 AM2, an emissivity of 0.75 was determined, whereas the emissivity of S Ni 6660 was 0.85 .

\subsection{Methods for non-destructive and destructive testing}

The finished wall structures have been subjected to a visual and dye penetration test. Subsequently, the samples were taken for further tests (see Fig. 3). First of all, a radiographic inspection was realised with the Eresco MF3 (GE S\&IT) Xray system of the General Electric Company. For this purpose, the central wall structure area has been mechanically processed, since the surface waviness of the wall structures makes it difficult to evaluate the X-ray images. This procedure achieves an image quality indicator of 16 acc. to [28].

OES was performed in the upper part of the bar on the surface of the milled bar. Then took place the removal of the two tensile samples in the welding direction, one cross ( $\mathrm{Y}-\mathrm{Z}$ plane) and one plane (Y-X plane) section each for macro- and microstructure investigations and samples for carrier gas melt extraction (CGME). The thickness of the flat tensile specimens and the initial gauge length for the elongation at break varied as a function of the wall structure width. The tensile specimens were tested at a test speed of $10 \mathrm{~mm} / \mathrm{min}$ on the Z250 testing machine (Zwick). On the Y-X plane sections, investigations were carried out on the primary dendrite arm spacing (PDAS) with 5 measurements each and on the segregation behaviour. The cross-sections were divided for preparation reasons. They were used to determine the bar dimensions and final contour proximity, the macro hardness, as well as the microstructure.

The macro-hardness was measured as HV 10 (1 kg load for a dwell time of $15 \mathrm{~s}$ ). The measurements were carried out from bottom to top (along straight line) either manually with the manual hardness tester DIA Testor 2 Rc (Otto-Wolpert Werke $\mathrm{GmbH}$ ) or automatically (one hardness impression per layer) with the fully automatic hardness tester Q60 A/A+ (Qness $\mathrm{GmbH})$. The preparation of the metallographic samples was carried out with grinding using silicon paper with several granulometries, followed by mechanical polishing using diamond paste with $3 \mu \mathrm{m}$ and end polishing with O.P.S $\left(\mathrm{SiO}_{2}\right)$ with $0.5 \mu \mathrm{m}$. To reveal the macro- and microstructure of the walls, colour etching acc. Beraha III and electrolytic etching 
Table 3 Setting and measuring values for CMT welding of the thin-walled structures as a function of the wire electrode

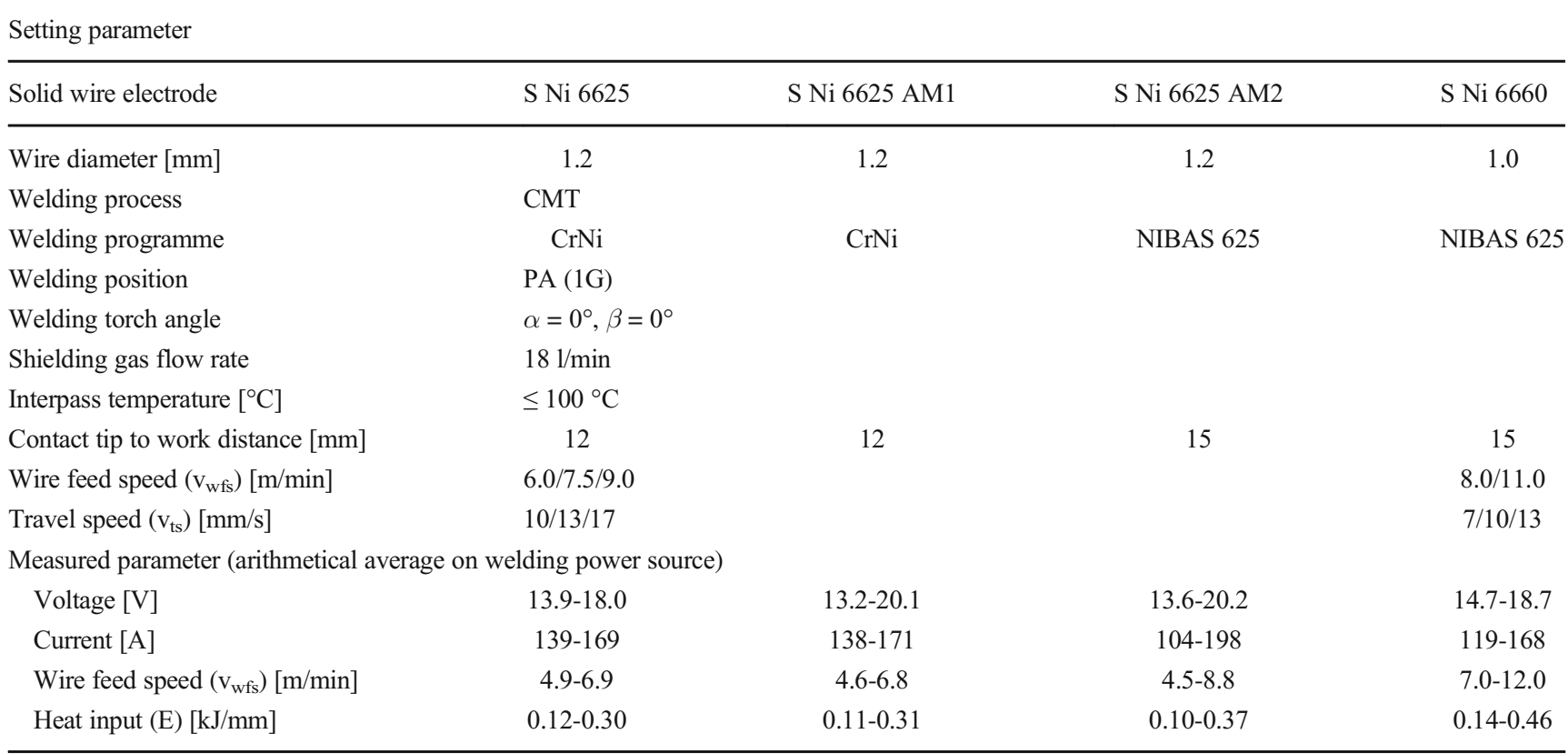

using aqueous solution with $10 \%$ chromic acid under $2.0 \mathrm{~V}$ for $15 \mathrm{~s}$ were used. The microstructure was investigated by light optical microscope (Inverse incident light microscope Leica MeF4A, Leica), scanning electron microscope (XL30 FEG/ESEM, company FEI/Philips) and energy dispersive spectrometer (EDAX Si (Li) detector).

\section{Results and discussion}

\subsection{Characterisation of the wire electrodes}

The chemical composition of the wire electrodes (see Table 4) is within the normative specifications (see Table 1) and show no divergences. The AM1 variant of S Ni 6625 has an $\mathrm{Fe}$ content of $4.81 \mathrm{wt} \%$, while the standard and AM2 variants only contain 0.23 , respectively, 0.20 wt $\%$ Fe. Furthermore, $\mathrm{S}$ Ni 6625 AM2 has slightly lower contents of $\mathrm{Nb}$ and $\mathrm{Si}$ and a smaller $\mathrm{C} / \mathrm{Nb}$ ratio than comparable wire electrodes. From a material point of view, both the $\mathrm{C} / \mathrm{Nb}$ ratio and the Si content influence which secondary phases are formed during solidification [29]. While a high $\mathrm{C} / \mathrm{Nb}$ ratio favours the formation of $\mathrm{NbC}$ carbides, low values lead to the exclusive formation of Laves phase. For average values, both phases can occur side by side. High Si contents favour the formation of the Laves phase. In the literature, the exclusive formation of a Laves phase is reported at values of $\mathrm{C} / \mathrm{Nb}=0.003$ and $\mathrm{Si}$ contents of at least $0.36 \mathrm{wt} \%$ [30]. Both Laves phase and $\mathrm{MC}$ carbide are observed at $\mathrm{C} / \mathrm{Nb}=0.01$ and $\mathrm{Si}$ contents of $0.46 \mathrm{wt} \%$ [31]. At lower values of Si content and higher $\mathrm{C} / \mathrm{Nb}$ (a)

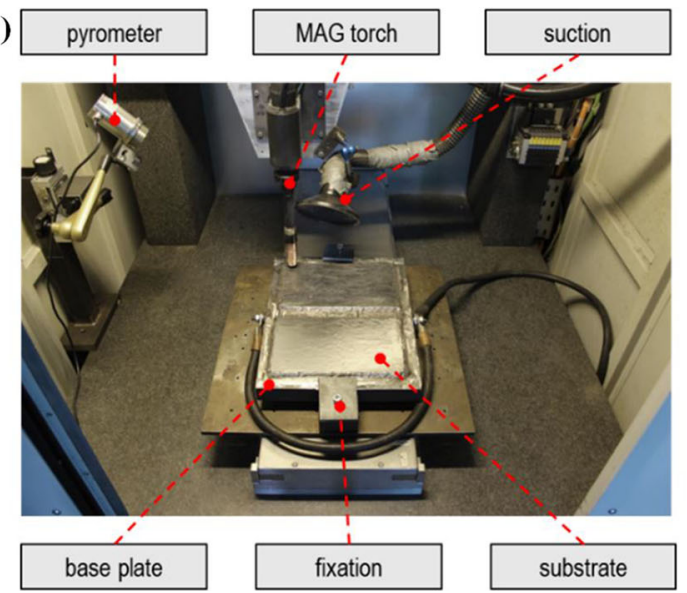

(b)

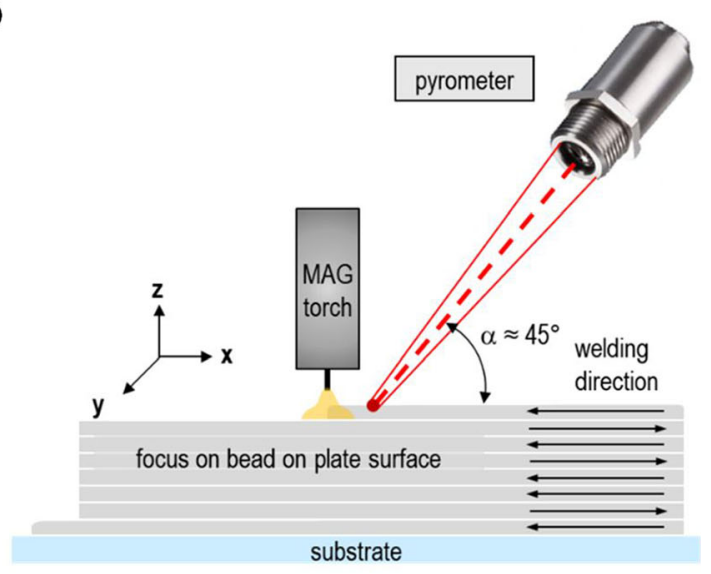

Fig. 1 Experimental setup and welding sequence (a) welding chamber (b) build-up strategy 
(a)

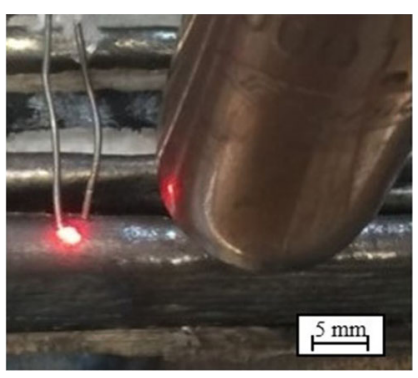

(b)

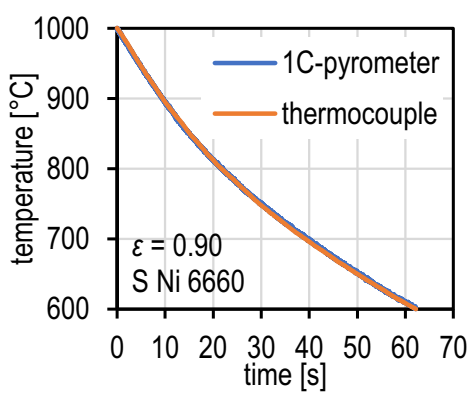

(c)

\begin{tabular}{ccc}
\hline emissivity & \multicolumn{2}{c}{ relative deviation } \\
\hline & $\begin{array}{c}1 \mathrm{C}- \\
\text { pyrometer }\end{array}$ & $\begin{array}{c}\text { thermo- } \\
\text { couple }\end{array}$ \\
\cline { 2 - 3 } 0.90 & $-0.1 \%$ & $100 \%$ \\
0.85 & $1.1 \%$ & $100 \%$ \\
0.80 & $1.7 \%$ & $100 \%$ \\
0.75 & $2.4 \%$ & $100 \%$ \\
0.70 & $4.0 \%$ & $100 \%$ \\
0.60 & $7.4 \%$ & $100 \%$ \\
0.50 & $13.3 \%$ & $100 \%$ \\
0.40 & $18.2 \%$ & $100 \%$
\end{tabular}

Fig. 2 Procedure for the pyrometer measurements (a) alignment of the pyrometer's focal point with the thermocouple spotted on the wall surface (b) temperature-time curves of thermocouple and IR pyrometer of wire

ratios, generally, only MC carbides are precipitated [32-34]. The welding filler S Ni 6660 has no niobium, the lowest $\mathrm{C}$ content and the highest $\mathrm{S}$ and $\mathrm{N}$ contents. The calculation of the pitting resistance equivalent (PREN) on the basis of the given chemical composition shows that $\mathrm{S}$ Ni 6600 achieves the highest value due to the $\mathrm{W}$-content. The differences in the $\mathrm{Nb}$-containing variants of S Ni 6625 are only slight.

$$
\operatorname{PREN}[\%]=\mathrm{Cr}+3.0 \times \mathrm{Mo}+16 \times \mathrm{N}+1.6 \times \mathrm{W}
$$

One of the basic requirements of a trouble-free gas-metal arc welding process is a permanently uniform feed of the wire electrode, even with hose packages of different lengths. The main factors influencing this are the surface condition of the wire electrode (roughness, roundness and foreign matter deposits), mechanical properties (tensile strength and buckling electrode S Ni 6660 for emissitivity $\varepsilon=0.90$ and (c) relative deviation of the $1 \mathrm{C}$-pyrometer from the thermocouple at different emissivities

stiffness) and also technological characteristics (cross-sectional tolerances and pre-bending). For application reasons, the wire electrode for gas-metal arc welding should have a high tensile strength with sufficient elongation at break to ensure high buckling stiffness even in long hose packages $[35,36]$. This is also given for all wire electrodes. Nevertheless, the standard variant has the highest tensile strength and lowest elongation at break, while the AM2 variant has the lowest strength and highest elongation at break (see Table 5). For the sliding behaviour in long hose assemblies, the basic rule is that with lower average roughness and greater pre-bending, the sliding ability of wire electrodes in the hose assembly increases [37]. S Ni 6625 AM2 and S Ni 6660 have the lowest average roughness values, which also correlate with the appearance of the wire electrode surfaces (matt/bright). Despite the different properties and characteristics, no significant

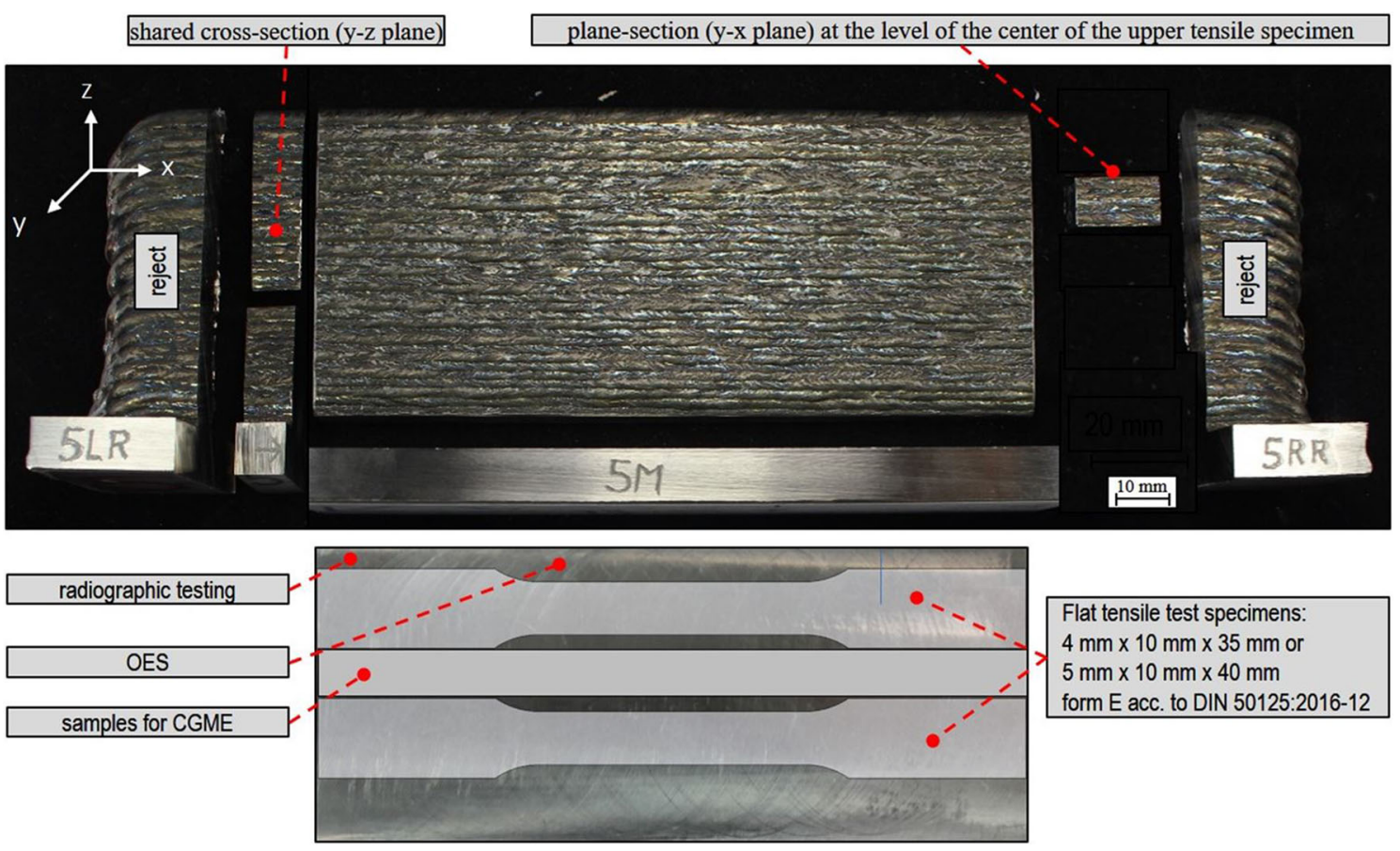

Fig. 3 Schematic illustration of the taking of specimens from welded thin-walled structures 
Table 4 Chemical composition of filler metals determined by OES (Button) and by CGME* (Solid wire)

\begin{tabular}{|c|c|c|c|c|c|c|c|c|c|c|c|c|}
\hline Filler metal & $\begin{array}{l}\mathrm{C}^{*} \\
{[\mathrm{wt} \%]}\end{array}$ & $\mathrm{Si}$ & $\mathrm{Mn}$ & $\mathrm{P}$ & $\mathrm{S}^{*}$ & $\mathrm{Cr}$ & Mo & $\mathrm{Fe}$ & $\mathrm{V}$ & W & $\mathrm{Cu}$ & $\mathrm{Al}$ \\
\hline S Ni 6625 & 0,014 & 0.08 & 0.01 & $<0.001$ & 0.0006 & 23.08 & 8.65 & 0.23 & 0.04 & 0.03 & 0.03 & 0.19 \\
\hline S Ni 6625 AM1 & 0.018 & 0.14 & 0.04 & $<0.001$ & 0.0002 & 23.01 & 8.91 & 4.81 & 0.05 & 0.04 & 0.01 & 0.22 \\
\hline S Ni 6625 AM2 & 0.011 & 0.08 & 0.01 & $<0.001$ & 0.0006 & 22.23 & 8.27 & 0.20 & 0.02 & 0.04 & $<0.01$ & 0.17 \\
\hline S Ni 6660 & 0.007 & 0.10 & 0.02 & $<0.001$ & 0.0040 & 21.83 & 9.27 & 0.26 & 0.02 & 2.89 & $<0.01$ & 0.10 \\
\hline Filler metal & $\begin{array}{c}\mathrm{Nb} \\
{[\mathrm{wt} \%]}\end{array}$ & $\mathrm{Ti}$ & $\mathrm{Zr}$ & $\mathrm{Ta}$ & $\mathrm{Mg}$ & $\mathrm{Ni}$ & $\begin{array}{c}\mathrm{O}^{*} \\
{[\mathrm{ppm}]}\end{array}$ & $\mathrm{N}^{*}$ & $\mathrm{H}^{*}$ & $\begin{array}{c}\text { PREN } \\
{[\%]}\end{array}$ & $\begin{array}{l}\mathrm{C} / \mathrm{Nb} \\
{[-]}\end{array}$ & \\
\hline S Ni 6625 & 3.52 & 0.19 & 0.01 & 0.04 & 0.01 & 63.87 & 31 & 147 & 6 & 51.9 & 0.004 & \\
\hline S Ni 6625 AM1 & 3.68 & 0.27 & 0.01 & 0.03 & 0.01 & 58.07 & 38 & 265 & 7 & 52.9 & 0.004 & \\
\hline S Ni 6625 AM2 & 4.13 & 0.22 & 0.01 & 0.03 & 0.01 & 64.58 & 35 & 122 & 9 & 49.8 & 0.003 & \\
\hline S Ni 6660 & 0.03 & 0.12 & 0.01 & 0.03 & 0.03 & 65.34 & 33 & 659 & 5 & 58.1 & - & \\
\hline
\end{tabular}

influence on the wire feeding and thus on the process behaviour was found under the selected test conditions.

\subsection{Welding process behaviour and cooling time}

Table 3 shows the mean values of the arithmetic averages of the individual weld layers of each bar. In function of wire feed and welding speed, the values for the heat input varied between 0.10 and $0.46 \mathrm{~kJ} / \mathrm{mm}$. The standard deviations for welding current and voltage have been calculated for the arithmetic mean values of the bars, which were calculated from the individual arithmetic mean values of each welding position of a bar (Fig. 4). Higher values in the standard deviations generally mean a slightly more unsteady process behaviour. Nevertheless, the droplet separation of the tough Ni melt can be controlled very well by the CMT process principle, and a sufficiently stable, low-spatter welding process can be achieved overall.

It should also be noted that there were sometimes deviations of up to $28 \%$ between the set and measured wire feed speed (Fig. 5). This is due to the fact that the used characteristic curves are created for defined boundary conditions (contact tip to work distance, material, shielding gas and welding position). Due to the deviating boundary conditions of the additive wall structure welds, there is, amongst other things, an internal control of the frequency of the wire backward movement and thus the wire feed speed.
IR pyrometers were used to measure the temperatures directly on the seam surface for every second layer at the wall structures of two wire electrodes during welding as a function of time. Since there is no specific temperature interval for the cooling time for Ni-based materials, this was calculated for cooling from $1000^{\circ} \mathrm{C}$ to $600^{\circ} \mathrm{C}$. In this temperature range, the precipitation of secondary phases takes place in many $\mathrm{Ni}$ based alloys. Figure 6 shows the determined cooling times as a function of welding position and heat input. Due to the faster heat conduction in the first layers, shorter cooling times occur here.

From about the 10th layer, the 3D heat dissipation changes to a $2 \mathrm{D}$ heat dissipation, which is why the cooling time remains almost constant. The fluctuations can result from slight differences in the interlayer temperature, which also influences the cooling time.

Figure 7 gives the arithmetic mean values of the $t_{10 / 6}$ cooling times from the $10^{\text {th }}$ position. As expected, the cooling times increase with increasing heat input. With the S Ni 6660, they reach a value of approx. $21 \mathrm{~s}$ at the highest heat input of $0.46 \mathrm{~kJ} / \mathrm{mm}$.

\subsection{Non-destructive testing}

The penetration test on the manufactured wall structures resulted in some indications independent of wire feed and welding speed (see Fig. 8).

Table 5 Mechanical properties at RT and roughness of solid wire electrodes

\begin{tabular}{|c|c|c|c|c|c|c|}
\hline Wire electrode & Diameter [mm] & Wire surface & Roughness Rz [ $\mu \mathrm{m}]$ & Cast $[\mathrm{mm}]$ & UTS [MPa] & $\mathrm{A}_{50 \mathrm{~mm}}[\%]$ \\
\hline S Ni 6625 & 1.18 & Matt & $1.26 \pm 0.34$ & 665 & $2031 \pm 26$ & $2.3 \pm 0.4$ \\
\hline S Ni 6625 AM1 & 1.18 & Dark matt & $1.00 \pm 0.08$ & 980 & $1608 \pm 28$ & $4.6 \pm 1.5$ \\
\hline S Ni 6625 AM2 & 1.18 & Glossy & $0.33 \pm 0.04$ & 760 & $1369 \pm 15$ & $9.9 \pm 1.1$ \\
\hline S Ni 6660 & 1.01 & Gglossy & $0.22 \pm 0.05$ & 980 & $1606 \pm 17$ & $3.5 \pm 1.2$ \\
\hline
\end{tabular}


Fig. 4 Standard deviations of the mean values for welding current and voltage as function of setting values for S Ni 6625, S Ni 6625 AM1 and S Ni 6625 AM2 (a, b) and for S Ni 6660 (c, d)

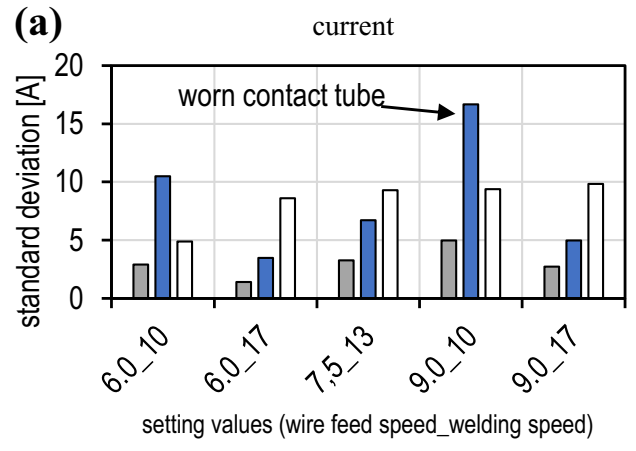

(c)

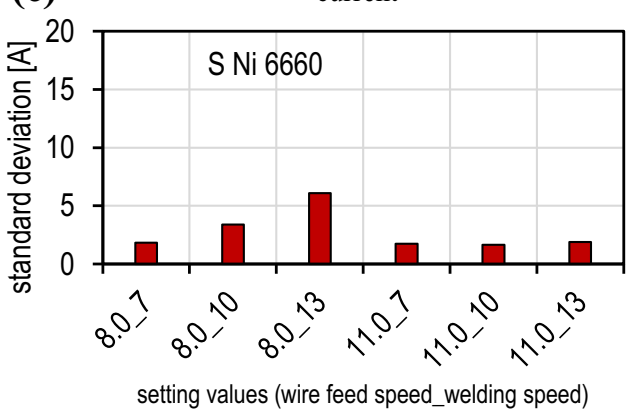

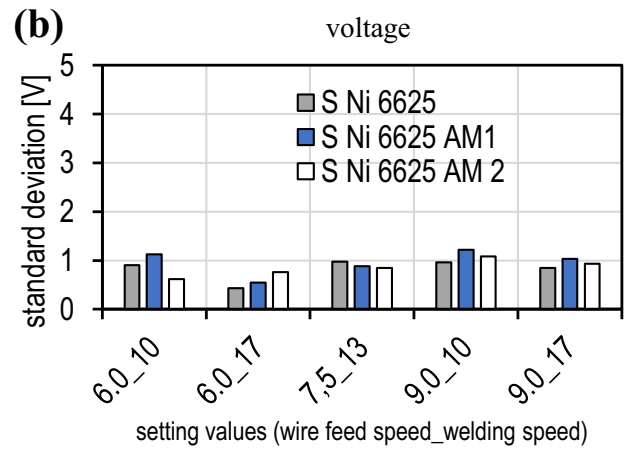

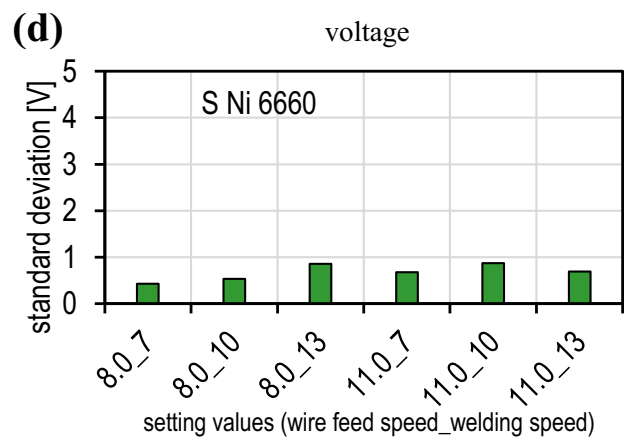

The appearance of the indications suggested surface pores. On the basis of the cross-sections, however, the indicators were classified as micro blowholes that can reach the surface. These micro blowholes, which are understood to be a spongelike or microporous structure, are preferably visible in the last welded layer (Fig. 9). Initially, it is assumed that the cause is a slight geometry-related lateral run-off of the melt. During solidification, the shrinkage of the Ni melt cannot be compensated and micro-pits are formed. In principle, this also occurs in the lower layers, but here, the micro blowholes are melted again by welding the next layer.

The radiographic examination revealed only a few small pores and no binding defects. The porosity, calculated according to equation 2, was below $0.001 \%$ for all wall structures and filler metals.

porosity $=\frac{\sum \text { size of pores }}{\text { measuring surface }} \quad[\%]$

\subsection{Macrostructure of the welded walls}

Figure 10 shows examples of macrosections of the wall structures of the filler metal S Ni 6625 AM2 and S Ni 6660. For automatic mechanical processing of the samples, it was necessary to cut the cross-sections in the middle. In some cases, comparatively large thickness reductions occurred in the lower wall structure area. To avoid this effect, an adjustment of the wire feed speed or, if necessary, preheating of the substrate sheets would be necessary, but this was not the focus of these investigations.

The final contour of the cross-sections was determined according to equation 3 in Fig. 11. Since the sections have been split, the lower value of the nominal wall structure width and the higher value of the actual bar width are relevant. During the evaluation, the upper rounded and the lower, partially constricted, areas of the samples were not considered. Nearly $80 \%$ of the wall structures reached a final contour of $\geq 75 \%$. As expected, the number of layers and the wall
Fig. 5 Percentage deviations between set and real wire feed speed (a) S Ni 6625, S Ni 6625 AM1, S Ni 6625 AM2 and (b) S Ni 6660 (a)

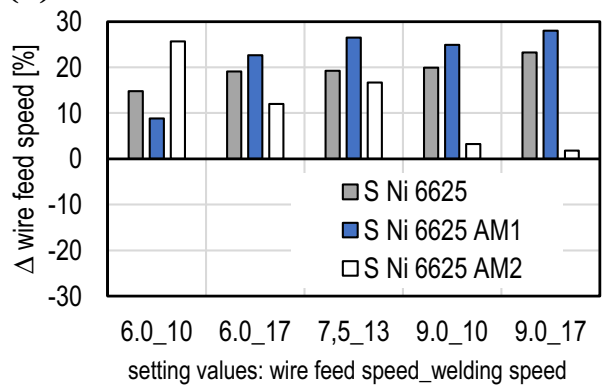

(b)

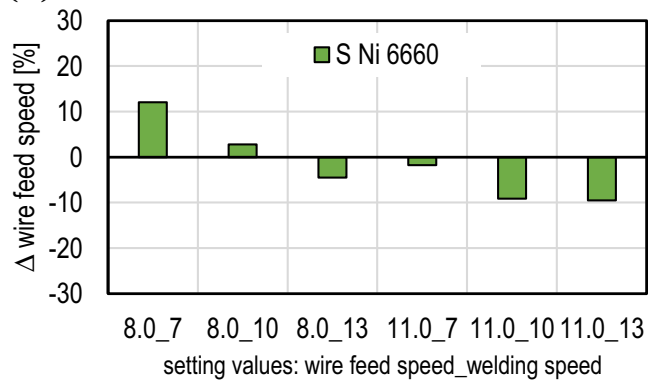


Fig. $6 t_{10 / 6}$ cooling times in the weld metal of S Ni 6625 AM2 (a) and S Ni 6660 (b) depending on the number of layers and heat input (a)

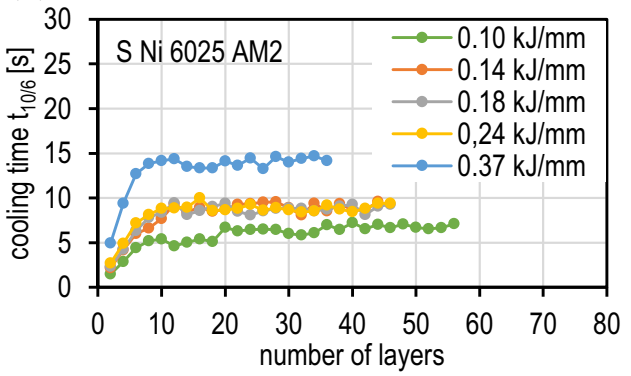

(b)

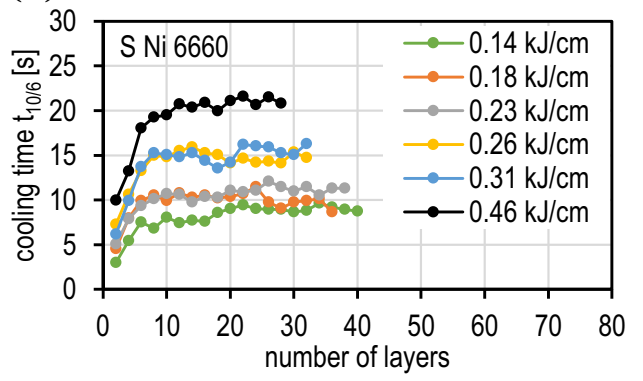

structure width increase with increasing heat input. The buildup rates are between 320 and $650 \mathrm{~cm}^{3} / \mathrm{h}$ depending on the parameters.

\subsection{Macro hardness of the wall structures}

Macro hardness was measured from sample deposited at deposited to top along vertical section. Figure 12, top left shows the average values calculated from 10 individual values depending on the filler metal used, independent of the setting values. The wall structures of the higher Fe alloyed wire electrode S Ni 6625 AM1 achieve the highest hardness. The hardness of the wall structures of the alloy-similar weld filler metals S 6625 and 6625 AM2 is lower and at a similar level. The weld metal of S Ni 6660 is the softest. No significant influence of the bare height on the hardness can be seen. The measurements were carried out exemplary for the wall structures with the highest heat input with one hardness impression per layer. In contrast, however, a slight increase in the average hardness of all wire electrodes was observed with increasing heat input (Fig. 12, bottom left). In comparison to the soft-annealed base material $244 \pm 6 \mathrm{HV} 10$, all weld metals are slightly softer.

\subsection{Mechanical properties}

Table 6 and Fig. 13 compare the determined mechanical properties of the different wall structures. These are average values from two tensile samples each. As expected, the wall structures of the higher Fe-containing weld filler metal S Ni 6625

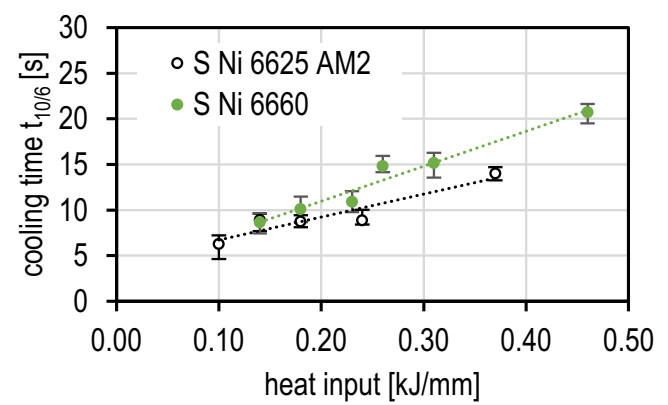

Fig. 7 Average $t_{10 / 6}$ cooling times in the weld metal of S Ni 6625 AM2 and $\mathrm{S} \mathrm{Ni} 6660$ as a function of heat input from the $10^{\text {th }}$ layer
AM1 achieve on average the highest tensile strength and yield tensile strength $\left(R_{p 0,2}\right)$ as well as the lowest elongation at break. The lowest strengths are shown by the wall structures of the W-containing S Ni 6660 . The chemically comparable S Ni 6625 AM1 has significantly lower tensile strength values and a comparable yield tensile strength $\left(R_{p 0,2}\right)$ compared to a soft-annealed $5 \mathrm{~mm}$ thick sheet of $\mathrm{Ni} 6625$.

In Ref. [17], wall structures manufactured for GTAWs with the same build-up strategy from S Ni 6625 with average tensile strengths of $722 \pm 17 \mathrm{MPa}$ and $42.3 \pm 2.4 \%$ for elongation at break are given (see Table 1). As the values for welding voltage or welding speed are not given, the heat input cannot be calculated. A direct comparison is therefore not possible.

In addition, it was observed in our own investigations that the strength values of all wire electrodes decrease slightly with increasing heat input (Fig. 14). A slight increase in elongation at break can be seen in the Ni 6625 weld metal type. This is attributed to the increase in the primary dendrite arm spacing (see Fig. 17 under point 3.8.). For example, in laser cladding samples made of S Ni 7718, it was found that a larger PDAS increases the proportion of segregation-induced brittle phases, which leads to lower strength values [38].

\subsection{Chemical analysis}

Since a schielding gas with low active and reducing gas components $\left(0.05 \% \mathrm{CO}_{2}\right.$ and $\left.2 \% \mathrm{H}_{2}\right)$ was used and no brushing between the individual layers took place, the chemical composition of the wall structures was determined by spectral analysis and melt extraction. Table 7 shows the results as a function of the wire electrodes used as an example of the lowest and highest heat input

For the highest heat input, the most intensive metallurgical reactions can be expected in the droplet stage. However, the results do not show any burn-off or burn-up reactions of alloying elements, even though no brushing took place between the individual layers. The small scattering results from measurement inaccuracies of the analysis methods. Likewise, the PREN calculated with equation (1) differs only very slightly. The $\mathrm{C} / \mathrm{Nb}$ ratio also calculated is lowest for the $\mathrm{S}$ Ni 6625 AM1 and highest for the S Ni 6625 AM2. 


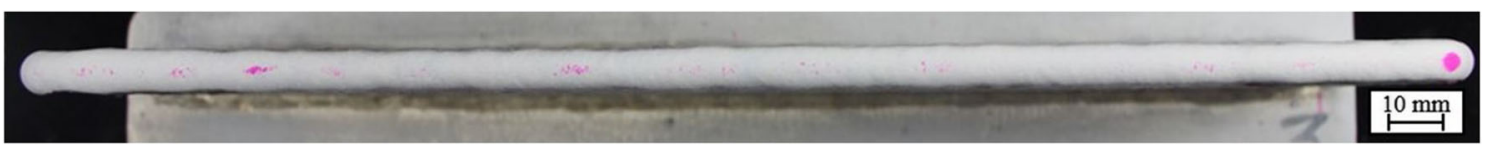

Fig. 8 Result of penetration testing of the last layer surface (S Ni 6625 AM2 with wire feed speed: $7.5 \mathrm{~m} / \mathrm{min}$, travel speed: $13 \mathrm{~mm} / \mathrm{min}$, heat input: 0.18 $\mathrm{kJ} / \mathrm{mm})$

A significant influence of the heat input on the contents of $\mathrm{C}, \mathrm{N}$ and $\mathrm{H}$ cannot be proven. Only in the case of oxygen, there is a greater scattering and a slight increase in values can be observed (Fig. 15). However, depending on the parameters, slightly increased contents of oxygen and nitrogen can be observed in the weld metal compared to the respective wire electrodes.

\subsection{Microstructure}

The typical microstructure of the cross-sections (x-z-plane) is shown in the middle of Fig. 16. As the heat flow direction of the solidifying weld pool is almost perpendicular to the surface of the previously welded layer or substrate, this leads to an epitaxial growth of the columnar dendrites almost parallel to the build-up direction, as described in [17]. The seam profile shows a finger-shaped penetration in the middle of the wall structure in each welded layer. In this zone, the PDAS for the selected example is approx. $9 \mu \mathrm{m}$ (Fig. 16, right), while in the weld metal area above it, it is approx. $20 \mu \mathrm{m}$ (Fig. 16, left). This grain refinement is attributed to a higher local cooling gradient.

The distances of the mostly equiaxial primary dendrite arms (PDAS) were measured in the middle of the wall structure on the plane sections (X-Y plane), which were taken at the height of the upper tensile sample. Figure 17 shows an increase in the distances for all welded wall structures with increasing heat input. As already documented in many publications [2, 19, 12, 25, 39], the weld metal of the niobium- and molybdenum-containing $\mathrm{Ni}$ based alloy S Ni 6625 has a strong tendency to segregation. For this reason, EDS analyses of segregation behaviour were carried out on the wall structure welds, which were each produced with the highest heat input. Table 8 gives an overview of the different chemical concentrations in the dendrite core $\left(C_{s}\right)$ and the global chemical compositions $\left(C_{0}\right)$ depending on the filler metal used.

For the quantitative measurements in the dendrite core and in the interdendritic areas, spot analyses were carried out at 5 points in each region. The global composition was determined with an area analysis $\left(A=0.11 \mathrm{~mm}^{2}\right)$. From the different compositions, the distribution coeffizient $(k)$, which is derived from the Scheil equation, can be calculated for each element according to equation 3 .

$k=C_{s} / C_{0}$

This procedure is described and justified in [12]. The calculated distribution coeffizient $(k)$ of $\mathrm{Al}, \mathrm{Cr}, \mathrm{Fe}$ and $\mathrm{Ni}$ are slightly higher than 1 and therefore indicate a slight segregation into the core. Mo, $\mathrm{Nb}$ and $\mathrm{Ti}$ show a distribution coeffizient $(k)$ less than 1 , indicating a tendency to segregate into the liquid metal during solidification and to accumulate in the interdendritic regions at the end of solidification. Niobium has the lowest $k$-values independent of the welding filler met$\mathrm{al}$, which indicates a more intensive segregation into the liquid metal than is the case with Mo. According to [12], this strong segregation of $\mathrm{Nb}$ is regarded as the cause for the formation of secondary phases in the microstructure of weld metal made of the alloy $\mathrm{Ni} 6625$. In the weld metal of the walled structures of S Ni 6660, we have not found strong segregations.

The microstructural investigations carried out so far on the SEM indicated the presence of two main types of secondary phases in the weld metal of type S Ni 6625 (regardless of whether standard or AM variant). SEM images at $2500 \times$ magnification give an overview of the microstructure of cross (Y-Z plane) sections (Fig. 18).
Fig. 9 Example of micro blowholes at the weld surface of the welded wall in the area of the indicators (a) microscope images (b) cross-section (Y-Z plane)
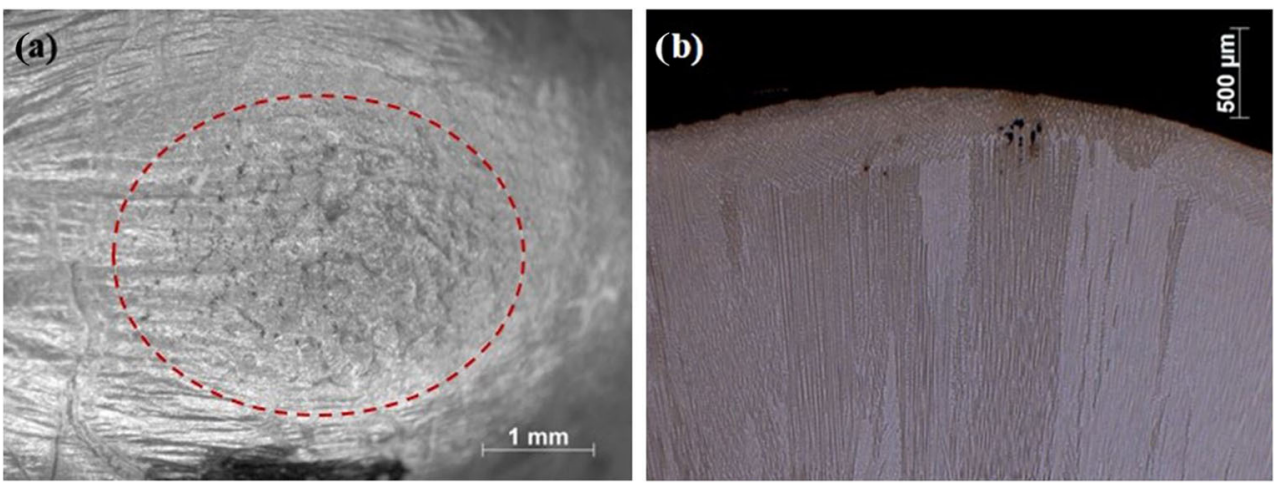


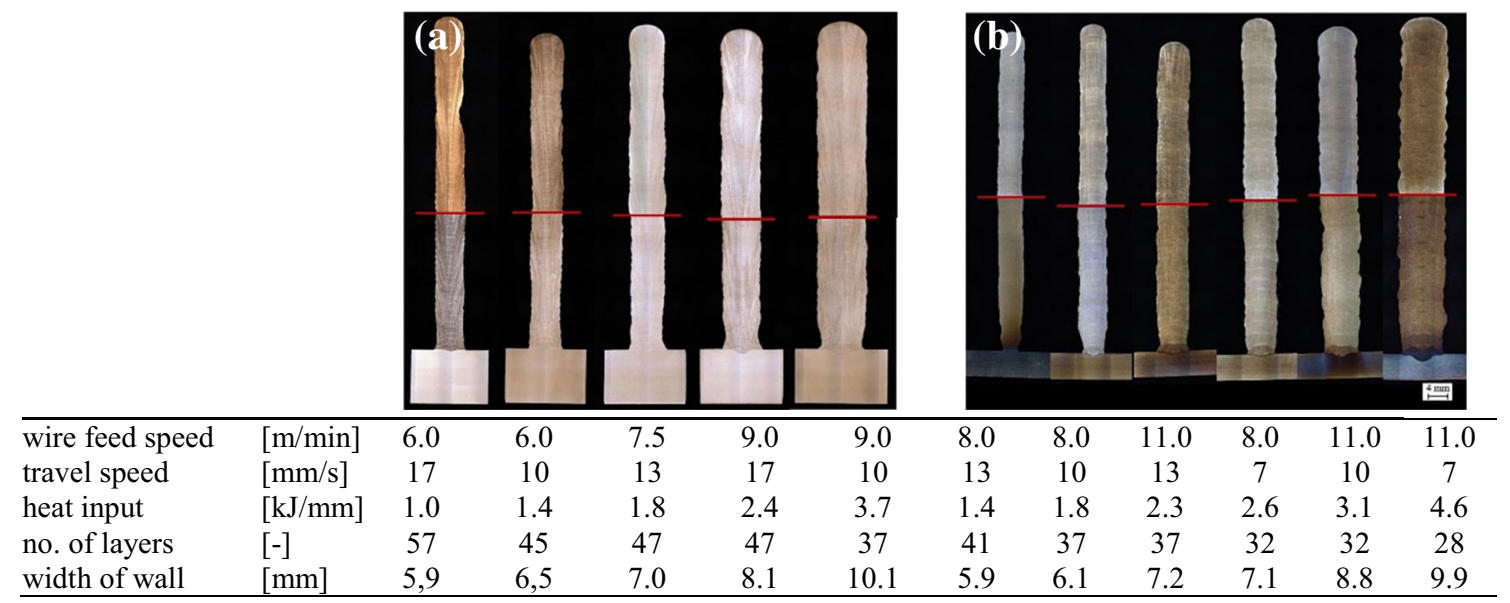

Fig. 10 Cross-sections (Y-Z plane) of the wall structures of S Ni 6625 AM2 (a) and S Ni 6660 (b)

One type of the interdendritic secondary phase has an elongated or rod-shaped form, which, according to the literature $[15,19,39,40]$, indicates Laves phase (see Fig. 19). The other cubic particles are TiN/NbC or NbC. In the weld metal of S Ni 6660, which contains $606 \mathrm{ppm}$ nitrogen and only $30 \mathrm{ppm}$ carbon, preferably cubic particles are visible. They are provisionally classified as nitrides according to colour and shape.

In the case of cubic TiN/NbC particles, a point inside is very often observed. This indicates the presence of $\mathrm{Mg}$ and also $\mathrm{Ca}$ or $\mathrm{Al}$ (see Figs. 19 and 20). $\mathrm{Ca}, \mathrm{Mg}, \mathrm{CaSi}$ and $\mathrm{MgSi}$ are added to high-purity steels and $\mathrm{Ni}$ alloys during smelting metallurgical production for complete deoxidation and desulfurization.

Despite the precipitation of the described secondary phases, unacceptable hot cracks, lack of fusions, or porosity did not occur in any of the fabricated webs of the various wire electrodes, indicating good suitability of alloy 625 for additive CMT welding.

(a)

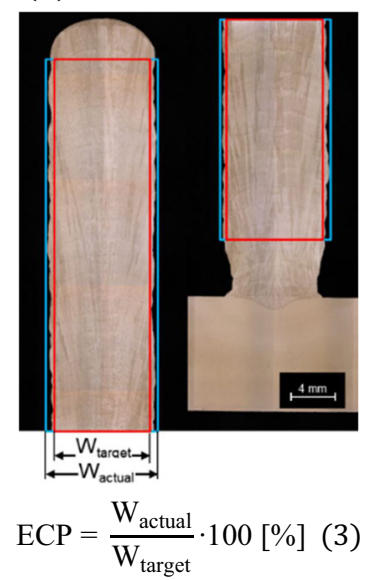

(b)

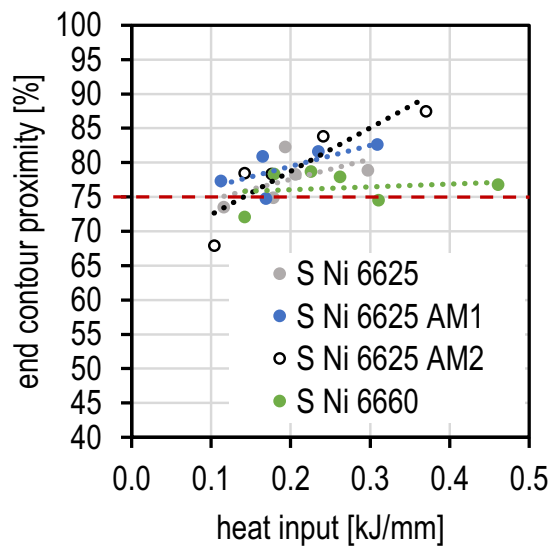

\subsection{Further studies}

Further investigations are planned into the influence of the filler metal on pitting corrosion resistance and hightemperature strength, as both are important for the practical use of additively welded structures made of S Ni 6625. Furthermore, the influence of additional shielding gases and modified component geometries (block instead of web) as well as the application of cooling measures during welding on the properties and microstructure will be investigated

\section{Conclusions}

The influence of heat input and filler metal composition on the technological aspects, mechanical properties and macro- and microstructure of additively welded thin-walled Ni-based structures was investigated. The heat input was varied between $0.10-0.46 \mathrm{~kJ} / \mathrm{mm}$ using the CMT process with shielding (c)

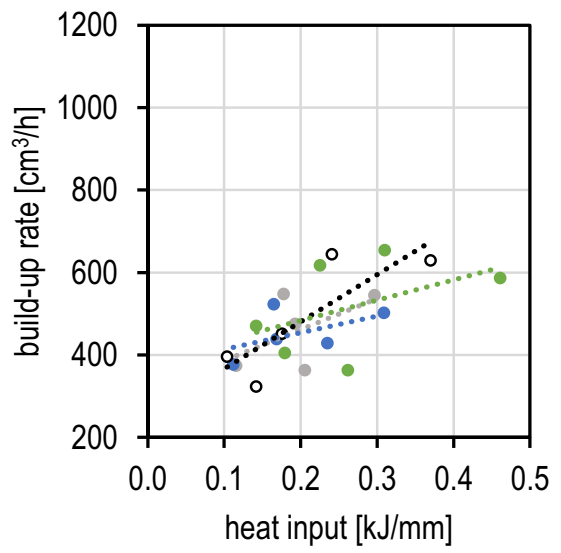

Fig. 11 (a) Procedure of determination of the end contour proximity (ECP) of the wall structures (b) results of ECP in function of heat input and (c) results of build-up rate in function of heat input 
(a)

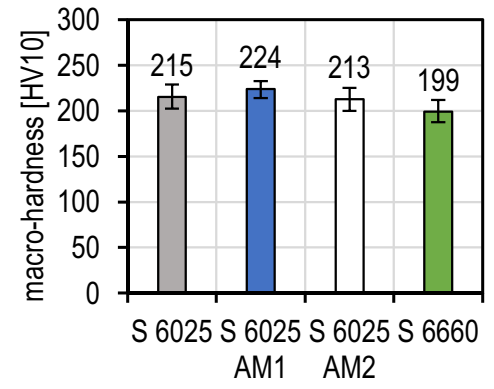

(b)

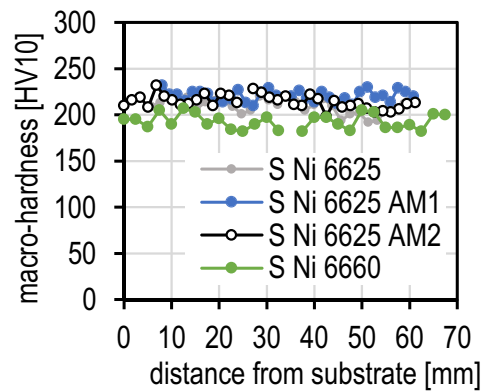

(c)

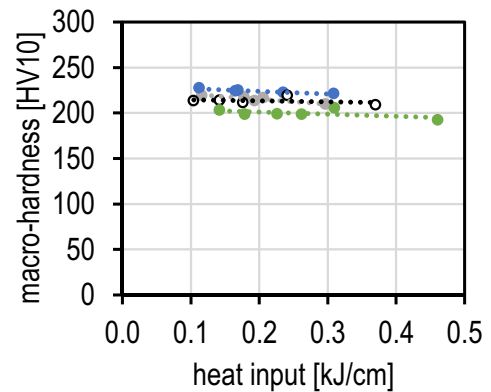

Fig. 12 Macro hardness as a function of wire electrode (a) mean values per wall (b) in function of distance from substrate and (c) in function of heat input

Table 6 Results of the tensile tests (average values from two flat tensile samples)

\begin{tabular}{|c|c|c|c|c|c|c|c|c|c|c|c|}
\hline \multirow{2}{*}{$\begin{array}{l}\text { Wire electrode } \\
\mathrm{v}_{\mathrm{wfs}}[\mathrm{m} / \mathrm{min}]\end{array}$} & \multicolumn{5}{|l|}{ S Ni 6625} & \multicolumn{6}{|c|}{ S Ni 6625 AM1 } \\
\hline & 6 & 6 & 7.5 & 9 & 9 & 6 & 6 & 7.5 & 9 & 9 & \\
\hline $\mathrm{v}_{\mathrm{ts}}[\mathrm{mm} / \mathrm{s}]$ & 10 & 17 & 13 & 10 & 17 & 10 & 17 & 13 & 10 & 17 & \\
\hline UTS [MPa] & $721 \pm 3$ & $694 \pm 3$ & $715 \pm 6$ & $704 \pm 33$ & $716 \pm 10$ & $733 \pm 1$ & $764 \pm 15$ & $754 \pm 3$ & $749 \pm 5$ & $743 \pm 9$ & \\
\hline $0.2 \% \mathrm{YS}[\mathrm{MPa}]$ & $413 \pm 27$ & $436 \pm 7$ & $432 \pm 12$ & $427 \pm 22$ & $452 \pm 23$ & $455 \pm 4$ & $487 \pm 45$ & $484 \pm 5$ & $464 \pm 28$ & $477 \pm 10$ & \\
\hline $\mathrm{A}[\%]$ & $55.0 \pm 0.1$ & $49.5 \pm 0.2$ & $53.2 \pm 4.9$ & $60.0 \pm 0.5$ & $51.0 \pm 3.0$ & $44.2 \pm 5.3$ & $44.7 \pm 1.1$ & $42.4 \pm 2.3$ & $47.4 \pm 0.2$ & $48.2 \pm 0.6$ & \\
\hline Wire electrode & \multicolumn{5}{|c|}{ S Ni 6625 AM2 } & \multicolumn{6}{|l|}{ S Ni 6660} \\
\hline $\mathrm{v}_{\mathrm{wfs}}[\mathrm{m} / \mathrm{min}]$ & 6 & 6 & 7.5 & 9 & 9 & 8 & 8 & 8 & 11 & 11 & 11 \\
\hline $\mathrm{v}_{\mathrm{ts}}[\mathrm{mm} / \mathrm{s}]$ & 10 & 17 & 13 & 10 & 17 & 7 & 10 & 13 & 7 & 10 & 13 \\
\hline UTS[MPa] & $721 \pm 7$ & $681 \pm 27$ & $700 \pm 4$ & $694 \pm 7$ & $688 \pm 28$ & $734 \pm 4$ & $725 \pm 0$ & $729 \pm 20$ & $681 \pm 12$ & $663 \pm 9$ & $685 \pm 3$ \\
\hline $0.2 \% \mathrm{YS}[\mathrm{MPa}]$ & $436 \pm 1$ & $419 \pm 4$ & $421 \pm 4$ & $415 \pm 3$ & $420 \pm 4$ & $426 \pm 4$ & $411 \pm 7$ & $423 \pm 15$ & $395 \pm 0$ & $398 \pm 7$ & $398 \pm 4$ \\
\hline $\mathrm{A}[\%]$ & $45.0 \pm 0.2$ & $42.6 \pm 7.0$ & $48.4 \pm 0.7$ & $46.5 \pm 5.2$ & $50.2 \pm 8.4$ & $50.7 \pm 1.4$ & $56.8 \pm 3.6$ & $51.5 \pm 1.8$ & $52.1 \pm 1.2$ & $45.5 \pm 4.0$ & $51.3 \pm 1.7$ \\
\hline
\end{tabular}

gas composition $30 \% \mathrm{He}, 2 \% \mathrm{H}_{2}, 0.05 \% \mathrm{CO}_{2}$ and bal. Ar. Three different filler metals of $\mathrm{Nb}$-alloyed $\mathrm{S} \mathrm{Ni} 6625$ (one standard version and two variants specially developed for additive welding) and the chemically similar, $\mathrm{Nb}$-free, but $\mathrm{W}$ alloyed filler metal S Ni 6660 were used in the investigations. The following conclusions can be drawn:
(1) The four wire electrodes have differences in the appearance of the wire surface, roughness and strength values. Nevertheless, no influence on the process stability of the CMT process could be detected. The standard deviation of the electrical parameters can be used to assess the process stability. The higher the standard deviation, the more unstable the process behaviour is
Fig. 13 Arithmetic mean values of mechanical properties of the welded thin-walled structures and substrate plate (soft-annealed) independent heat input (a) ultimate and yield strength (b) elongation (a)

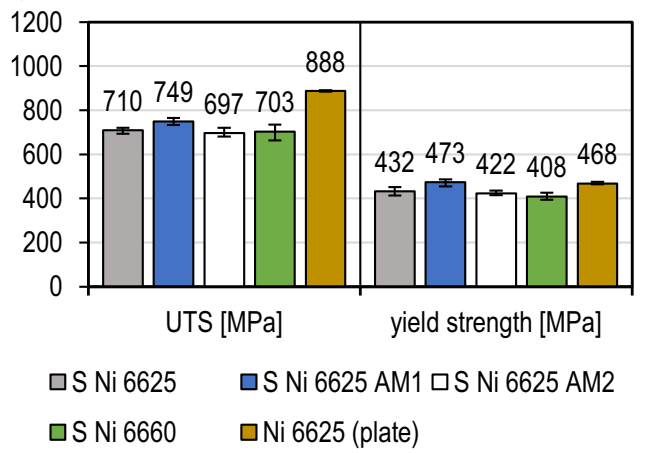

(b)

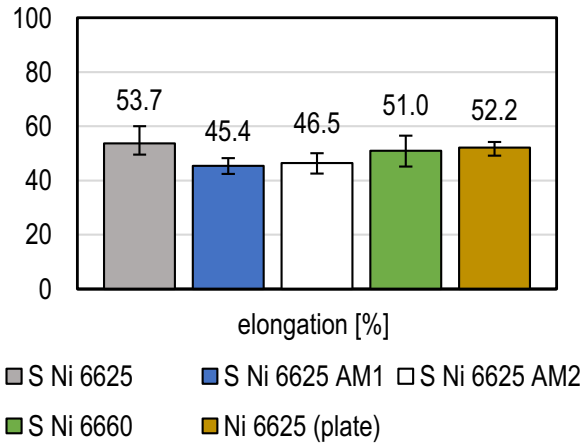


(a)

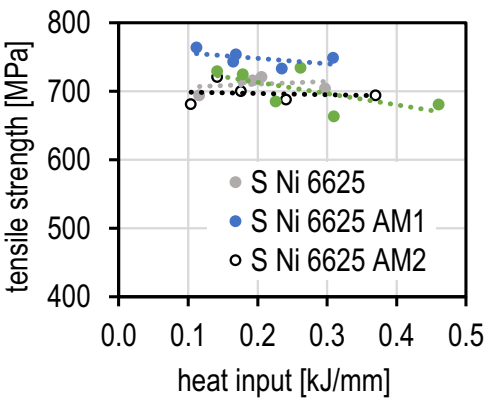

(b)

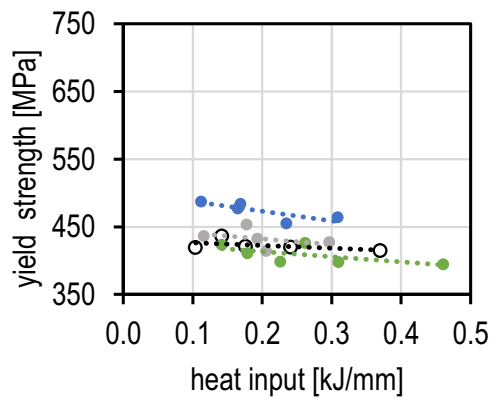

(c)

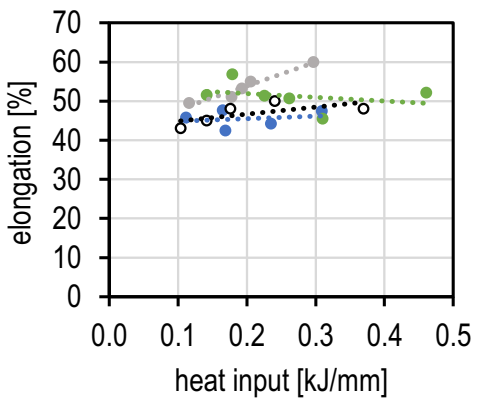

Fig. 14 Mechanical properties of the welded thin-walled structures dependent of heat input and wire electrode (a) ultimate tensile strength, (b) yield strength and (c) elongation

Table 7 Chemical compositions (wt \%) of welded thin-walled structures determined by OES and by CGME*

\begin{tabular}{|c|c|c|c|c|c|c|c|c|c|c|c|c|c|}
\hline Filler metal & $\begin{array}{c}\mathrm{E} \\
{[\mathrm{kJ} / \mathrm{mm}]}\end{array}$ & $\begin{array}{c}\mathrm{C}^{*} \\
{[\mathrm{wt} \%]}\end{array}$ & $\mathrm{Si}$ & $\mathrm{Mn}$ & $\mathrm{P}$ & $\mathrm{S}^{*}$ & $\mathrm{Cr}$ & Mo & $\mathrm{Fe}$ & V & W & $\mathrm{Cu}$ & $\mathrm{Al}$ \\
\hline \multirow[t]{2}{*}{ S Ni 6625} & 0.12 & 0.015 & 0.08 & 0.01 & $<0.001$ & 0.0002 & 23.13 & 8.87 & 0.14 & 0.05 & 0.03 & 0.03 & 0.18 \\
\hline & 0.30 & 0.015 & 0.08 & 0.01 & $<0.001$ & 0.0003 & 23.76 & 9.00 & 0.13 & 0.05 & 0.03 & 0.03 & 0.18 \\
\hline \multirow[t]{2}{*}{ S Ni 6625 AM1 } & 0.11 & 0.024 & 0.14 & 0,04 & $<0.001$ & 0.0012 & 23.53 & 8.82 & 4.89 & 0.05 & 0.04 & 0.01 & 0.22 \\
\hline & 0.31 & 0.018 & 0.15 & 0.04 & $<0.001$ & 0.0015 & 23.33 & 8.84 & 4.91 & 0.05 & 0.04 & 0.01 & 0.21 \\
\hline \multirow[t]{2}{*}{ S Ni 6625 AM2 } & 0.10 & 0.008 & 0.08 & 0.01 & $<0.001$ & 0.0003 & 21.94 & 8.32 & 0.17 & 0.03 & 0.03 & $<0.01$ & 0.18 \\
\hline & 0.37 & 0.008 & 0.08 & 0.01 & $<0.001$ & 0.0004 & 22.24 & 8.20 & 0.17 & 0.03 & 0.03 & $<0.01$ & 0.18 \\
\hline \multirow[t]{2}{*}{ S Ni 6660} & 0.14 & 0.003 & 0.10 & 0.02 & $<0.001$ & 0.0038 & 21.98 & 9.42 & 0.26 & 0.02 & 2.87 & $<0.01$ & 0.09 \\
\hline & 0.46 & 0.003 & 0.10 & 0.02 & $<0.001$ & 0.0040 & 21.96 & 9.42 & 0.26 & 0.02 & 2.87 & $<0.01$ & 0.09 \\
\hline \multirow[t]{2}{*}{ Filler metal } & $\mathrm{E}$ & $\mathrm{Nb}$ & $\mathrm{Ti}$ & $\mathrm{Zr}$ & $\mathrm{Ta}$ & $\mathrm{Mg}$ & $\mathrm{Ni}$ & $\mathrm{O}^{*}$ & $\mathrm{~N}^{*}$ & $\mathrm{H}^{*}$ & PREN & $\mathrm{C} / \mathrm{Nb}$ & \\
\hline & {$[\mathrm{kJ} / \mathrm{mm}]$} & [wt\%] & & & & & & {$[\mathrm{ppm}]$} & & & {$[\%]$} & {$[-]$} & \\
\hline \multirow[t]{2}{*}{ S Ni 6625} & 0.12 & 3.64 & 0.20 & 0.01 & 0.03 & 0.02 & 63.55 & 23 & 201 & 3 & 52.8 & 0.004 & \\
\hline & 0.30 & 3.63 & 0.19 & 0.01 & 0.04 & 0.02 & 62.87 & 26 & 218 & 3 & 53.9 & 0.004 & \\
\hline \multirow[t]{2}{*}{ S Ni 6625 AM1 } & 0.11 & 3.56 & 0.26 & 0.01 & 0.03 & 0.02 & 57.64 & 15 & 294 & 4 & 53.2 & 0.007 & \\
\hline & 0.31 & 3.56 & 0.28 & 0.01 & 0.03 & 0.02 & 57.80 & 55 & 357 & 5 & 53.1 & 0.005 & \\
\hline \multirow[t]{2}{*}{ S Ni 6625 AM2 } & 0.10 & 4.30 & 0.22 & 0.01 & 0.03 & 0.01 & 64.67 & 34 & 233 & 6 & 49.8 & 0.002 & \\
\hline & 0.37 & 4.26 & 0.22 & 0.01 & 0.03 & 0.01 & 64.53 & 40 & 182 & 5 & 49.6 & 0.002 & \\
\hline \multirow[t]{2}{*}{ S Ni 6660} & 0.14 & 0.03 & 0.12 & 0.01 & 0.03 & 0.03 & 65.01 & 36 & 631 & 4 & 58.7 & --- & \\
\hline & 0.46 & 0.03 & 0.12 & 0.01 & 0.03 & 0.03 & 65.04 & 62 & 609 & 4 & 58.6 & --- & \\
\hline
\end{tabular}

(a)

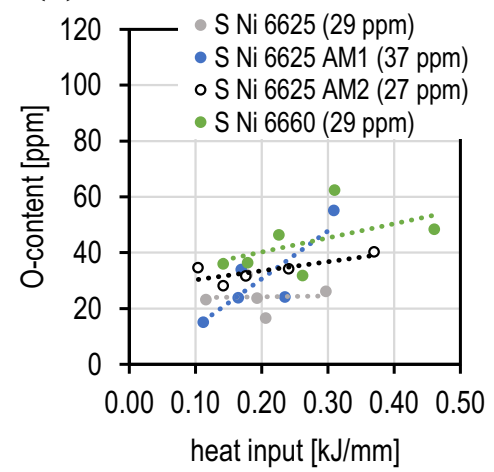

(b)

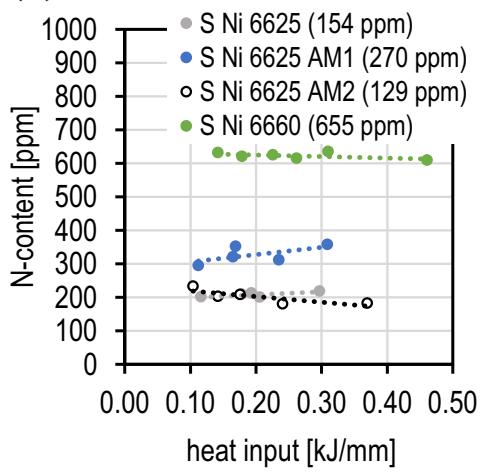

(c)

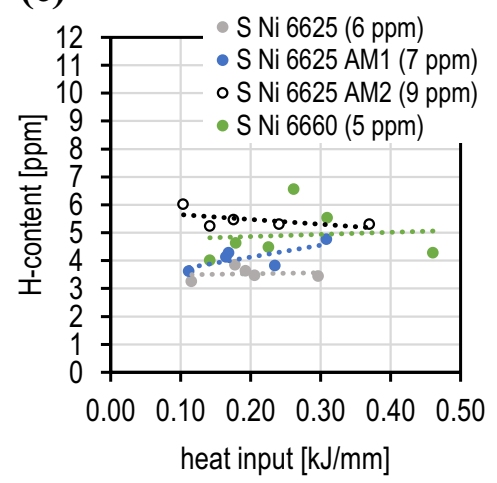

Fig. 15 Gas contents of the bars as a function of wire electrode and heat input (a) oxygen, (b) nitrogen and (c) hydrogen 


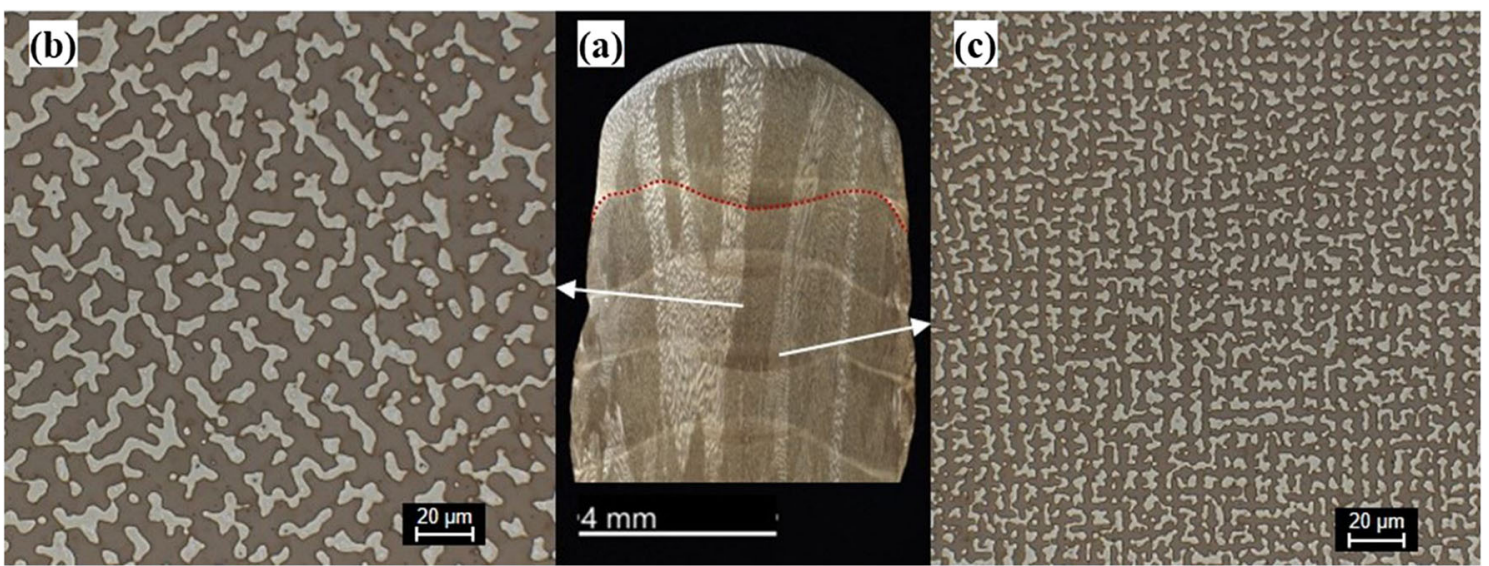

Fig. 16 Macrostructure of a wall structure (Y-Z plane) with epitaxial dendrite growth (a) and microstructure (X-Y plane) in the middle (b) and in the lower area (c) of the CMT weld bead

(2) Due to the low arc power and the integrated wire movement in the melting process, the CMT process is very suitable for the production of additively welded thinwalled structures from Ni-based welding filler despite the high viscosity of the Ni melt. Please note the possible deviations between the set and real wire feed

(3) Variable width and height of the wall structures can be adjusted via the wire feed and welding speed. The build-up rates are between 320 and $650 \mathrm{~cm}^{3} / \mathrm{h}$ depending on the parameters. $80 \%$ of the wall structures achieved the required final contour proximity of at least $75 \%$

(4) Because of the interpass temperatures and the slow heat conduction due to the geometry, the pure welding time is about 3-7 \% of the total production time of a wall structure. For this reason, the development of suitable cooling strategies is absolutely necessary

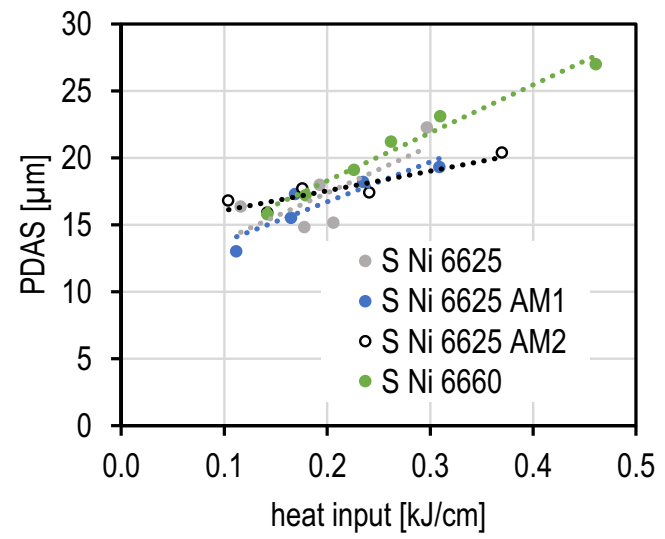

Fig. 17 PDAS as a function of wire electrode an heat input
(5) $t_{10 / 6}$ cooling times increase significantly with increasing number of layers and heat input. From the $10^{\text {th }}$ layer at the latest, the $3 \mathrm{D}$ heat conduction changes into a $2 \mathrm{D}$ heat conduction and the cooling times stabilise. The average $t_{10 / 6}$ cooling then amount to about 6-21 s from the 10th layer onwards, depending on the heat input

(6) The wall structures produced have a very low porosity, no hot cracks and no binding defects. Only in the area of the last layer are micro-pits visible, which can reach the surface. Initially, it is assumed that the cause is a slight geometry-related lateral run-off of the melt. During solidification, this shrinkage of the Ni melt cannot be compensated and micro-pits are formed. If this area is further mechanically processed, no influence on the corrosion resistance can be assumed

(7) The mechanical properties of the wall structures depend on the filler metal used and the heat input. Basically, the strength is slightly reduced with increasing heat input, irrespective of the filler metal. The S Ni 6625 AM1 (high Fe content), which is similar to the base material, achieves the highest yield tensile strength $\left(R_{p 0,2}\right)$. This is at base material level. However, the elongation at break is lower than that of the base material. The lowest yield tensile strength $\left(R_{p 0,2}\right)$ is found in the welded wall structures of the W-containing filler metal S Ni 6660

(8) No burn-off or additional burn-up of alloying elements in the weld metal occurred despite the slightly active shielding gas. However, there is sometimes an increase in oxygen and nitrogen compared to the wire electrodes

(9) The primary dendrite arm spacing, whose values are between 13 and $27 \mu \mathrm{m}$, increases with increasing heat input 
Table 8 Chemical composition in the dendrite nucleus $\left(C_{s}\right)$, in interdendritic region $\left(C_{i}\right)$ and the global chemical composition $\left(C_{0}\right)$, as well as the partitioning coefficient $k$

\begin{tabular}{|c|c|c|c|c|c|c|c|c|c|c|c|c|}
\hline \multirow[t]{2}{*}{ Element } & \multicolumn{4}{|c|}{ S Ni 6625} & \multicolumn{4}{|c|}{ S Ni 6625 AM1 } & \multicolumn{4}{|c|}{ S Ni 6625 AM2 } \\
\hline & $C_{0}$ & $C_{S}$ & $\mathrm{Ci}$ & $k$ & $C_{0}$ & $C_{S}$ & $C i$ & $k$ & $C_{0}$ & $C_{S}$ & $C i$ & $k$ \\
\hline $\mathrm{Al}$ & 0.40 & $0.42 \pm 0.05$ & $0.38 \pm 0.06$ & 1.06 & 0.40 & $0.41 \pm 0.14$ & $0.35 \pm 0.15$ & 1.03 & 0.29 & $0.37 \pm 0.12$ & $0.26 \pm 0.12$ & 1.27 \\
\hline $\mathrm{Nb}$ & 4.35 & $2.52 \pm 0.21$ & $4.56 \pm 0.50$ & 0.58 & 4.53 & $2.42 \pm 0.28$ & $5.91 \pm 0.80$ & 0.53 & 4.21 & $2.34 \pm 0.12$ & $4.45 \pm 1.08$ & 0.56 \\
\hline Mo & 9.52 & $8.48 \pm 0.19$ & $\begin{array}{c}10.08 \\
\pm 0.48\end{array}$ & 0.89 & 10.25 & $8.48 \pm 0.23$ & $\begin{array}{c}10.98 \\
\pm 0.52\end{array}$ & 0.83 & 9.6 & $8.49 \pm 0.13$ & $9.84 \pm 0.44$ & 0.88 \\
\hline $\mathrm{Ti}$ & 0.31 & $0.26 \pm 0.06$ & $0.29 \pm 0.03$ & 0.82 & 0.38 & $0.27 \pm 0.03$ & $0.33 \pm 0.07$ & 0.72 & 0.37 & $0.27 \pm 0.05$ & $0.29 \pm 0.08$ & 0.72 \\
\hline $\mathrm{Cr}$ & 21.57 & $\begin{array}{l}22.01 \\
\pm 0.18\end{array}$ & $\begin{array}{l}22.01 \\
\pm 0.26\end{array}$ & 1.02 & 22.04 & $\begin{array}{l}22.38 \\
\pm 0.23\end{array}$ & $\begin{array}{c}21.44 \\
\pm 0.40\end{array}$ & 1.02 & 21.91 & $\begin{array}{l}21.98 \\
\pm 0.17\end{array}$ & $\begin{array}{c}21.74 \\
\pm 0.38\end{array}$ & 1.00 \\
\hline $\mathrm{Fe}$ & 0.41 & $0.52 \pm 0.09$ & $0.53 \pm 0.08$ & 1.26 & 5.04 & $5.28 \pm 0.16$ & $4.61 \pm 0.31$ & 1.05 & 0.58 & $0.62 \pm 0.04$ & $0.59 \pm 0.10$ & 1.07 \\
\hline $\mathrm{Ni}$ & 63.44 & $\begin{array}{l}65.79 \\
\pm 0.20\end{array}$ & $\begin{array}{c}62.15 \\
\pm 0.79\end{array}$ & 1.04 & 57.36 & $\begin{array}{l}60.77 \\
\pm 0.63\end{array}$ & $\begin{array}{c}56.39 \\
\pm 0.61\end{array}$ & 1.06 & 63.05 & $\begin{array}{c}65.92 \\
\pm 0.23\end{array}$ & $\begin{array}{c}62.84 \\
\pm 1.19\end{array}$ & 1.05 \\
\hline
\end{tabular}

for all filler metals. This is also the reason for the slightly decreasing strength values in the weld metal

(10) In all S Ni 6625 type weld metal, the elements Nb, Mo and $\mathrm{Ti}$ tend to be segregated. This results in the formation of secondary phases (Laves phase and carbide/ nitride $(\mathrm{NbC}$ or $\mathrm{NbC} / \mathrm{TiN}))$. This is often reported in the literature. The $\mathrm{C} / \mathrm{Nb}$ ratio is highest in the welded wall structures of S Ni 6625 AM1 and lowest in those of S Ni 6625 AM2. The proportions of secondary phases in the weld metal of the Fe containing wire electrode S Ni 6625 AM1 are subjectively also slightly higher.
Fig. 18 SEM with secondary electron detector on cross (Y-Z plane) sections of CMT weld metal microstructures in the upper layers of the walled structures (a) S Ni 6625, heat input: $0.30 \mathrm{~kJ} /$ $\mathrm{mm}$, (b) S Ni 6625 AM1, heat input: $0.31 \mathrm{~kJ} / \mathrm{mm}$, (c) S Ni 6625 AM2, heat input: $0.37 \mathrm{~kJ} / \mathrm{mm}$ and (d) S Ni 6660, heat input: $0.46 \mathrm{~kJ} /$ $\mathrm{mm}$
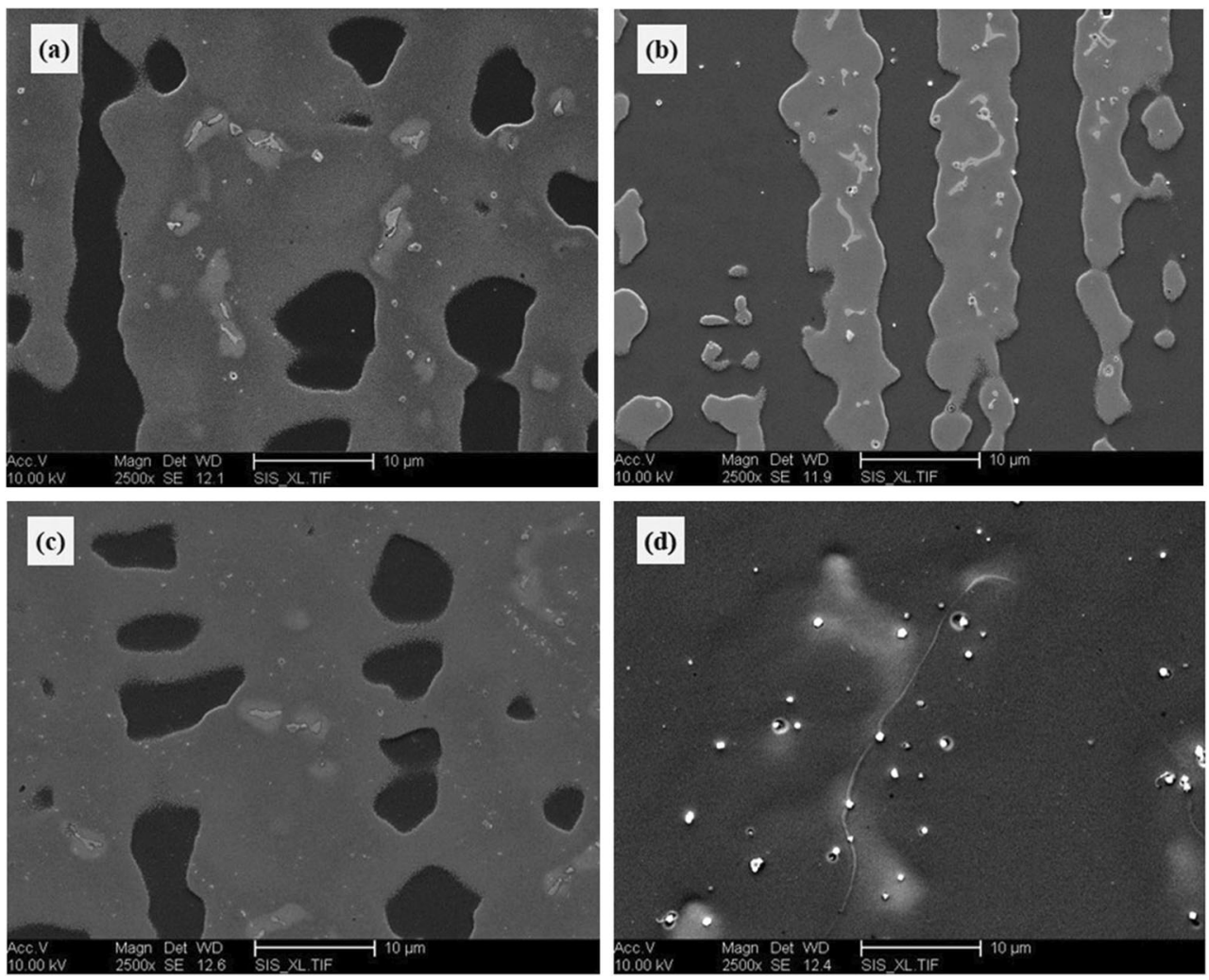


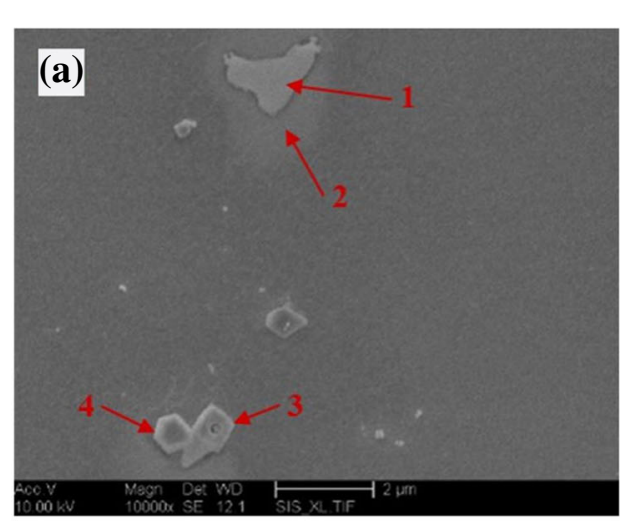

\begin{tabular}{ccccc}
\hline $\begin{array}{c}\text { Element } \\
\text { wt\% }\end{array}$ & $\begin{array}{c}\text { Laves } \\
\text { phase }\end{array}$ & $\begin{array}{c}\text { by the } \\
\text { Laves phase }\end{array}$ & $\begin{array}{c}\mathrm{TiN} / \\
\mathrm{NbC}\end{array}$ & $\begin{array}{c}\mathrm{TiN} / \\
\mathrm{NbC}\end{array}$ \\
\hline & 1 & 2 & 3 & 4 \\
\cline { 2 - 5 } $\mathrm{C} \mathrm{K}$ & 9.48 & 1.94 & 2.25 & 3.16 \\
$\mathrm{~N} \mathrm{~K}$ & & & 5.54 & 7.51 \\
$\mathrm{Mg} \mathrm{K}$ & & & 1.72 & \\
$\mathrm{Al} \mathrm{K}$ & & & 0.83 & \\
$\mathrm{Si} \mathrm{K}$ & 0.57 & 0.19 & & \\
$\mathrm{Nb} \mathrm{L}$ & 18.00 & 7.39 & 50.98 & 49.19 \\
$\mathrm{MoL}$ & 17.75 & 10.01 & 3.08 & 3.14 \\
$\mathrm{Ti} \mathrm{K}$ & & & 22.72 & 22.35 \\
$\mathrm{CrK}$ & 13.82 & 16.62 & 4.40 & 4.61 \\
$\mathrm{Ni} \mathrm{K}$ & 40.38 & 63.85 & 8.49 & 10.04 \\
$\mathrm{Total}$ & 100.00 & 100.00 & 100.00 & 100.00 \\
\hline
\end{tabular}

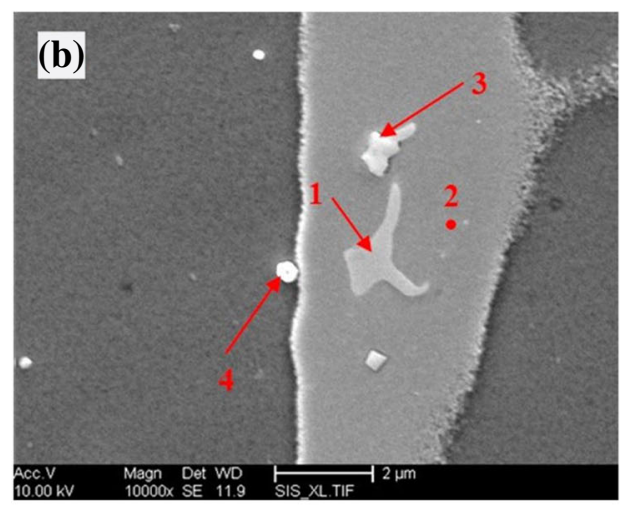

\begin{tabular}{|c|c|c|c|c|c|}
\hline $\begin{array}{c}\text { Element } \\
\text { wt \% }\end{array}$ & $\begin{array}{l}\text { Laves } \\
\text { phase }\end{array}$ & \multicolumn{2}{|c|}{$\begin{array}{c}\text { by the Laves } \\
\text { phase }\end{array}$} & $\mathrm{NbC}$ & $\begin{array}{l}\mathrm{TiN} / \\
\mathrm{NbC}\end{array}$ \\
\hline & 1 & \multicolumn{2}{|c|}{2} & 3 & 4 \\
\hline $\mathrm{C} \mathrm{K}$ & 15.97 & \multirow{2}{*}{\multicolumn{2}{|c|}{11.26}} & 12.92 & 4.26 \\
\hline N K & & & & & 6.41 \\
\hline Si K & 0.84 & \multicolumn{2}{|c|}{0.28} & 0.43 & 0.21 \\
\hline $\mathrm{Nb} \mathrm{L}$ & 12.66 & \multicolumn{2}{|c|}{7.12} & 54.38 & 16.49 \\
\hline MoL & 15.44 & \multirow{2}{*}{\multicolumn{2}{|c|}{10.79}} & 11.10 & 6.66 \\
\hline Ti K & & & & & 24.96 \\
\hline $\mathrm{Cr} \mathrm{K}$ & 12.71 & \multicolumn{2}{|c|}{17.99} & 6.08 & 15.61 \\
\hline $\mathrm{Fe} \mathrm{K}$ & 3.91 & \multicolumn{2}{|c|}{3.21} & 1.76 & 3.32 \\
\hline Ni K & 38.48 & \multicolumn{2}{|c|}{49.34} & 13.35 & 22.08 \\
\hline Total & 100.0 & \multicolumn{2}{|c|}{100.00} & 100.00 & 100.00 \\
\hline \multirow[t]{2}{*}{$\begin{array}{c}\text { Element } \\
\text { wt } \%\end{array}$} & $\begin{array}{l}\text { Laves } \\
\text { phase }\end{array}$ & $\begin{array}{l}\text { by the } \\
\text { Laves } \\
\text { phase }\end{array}$ & $\begin{array}{l}\mathrm{TiN} / \\
\mathrm{NbC}\end{array}$ & $\begin{array}{l}\mathrm{TiN} / \\
\mathrm{NbC}\end{array}$ & $\begin{array}{l}\mathrm{TiN} / \\
\mathrm{NbC}\end{array}$ \\
\hline & 1 & 2 & 3 & 4 & 5 \\
\hline $\mathrm{C} \mathrm{K}$ & 13.13 & 2.87 & 4.81 & 6.88 & 3.12 \\
\hline N K & & & 6.33 & 3.65 & 2.89 \\
\hline Si K & 0,74 & 0.33 & & & \\
\hline $\mathrm{Mg} \mathrm{K}$ & & & & & 3.78 \\
\hline $\mathrm{Nb} \mathrm{L}$ & 16.57 & 8.97 & 49.93 & 62.01 & 52.27 \\
\hline $\mathrm{MoL}$ & 17.05 & 12.01 & 4.21 & 5.14 & 12.95 \\
\hline $\mathrm{Ca} \mathrm{K}$ & & & & & 5.14 \\
\hline Ti K & & & 18.90 & 5.97 & 10.79 \\
\hline $\mathrm{Cr} \mathrm{K}$ & 15.34 & 21.65 & 5.65 & 5.67 & 5.14 \\
\hline Ni L & 37.17 & 54.18 & 10.17 & 10.68 & 3.91 \\
\hline Total & 100.0 & 100.00 & 100.00 & 100.00 & 100.00 \\
\hline
\end{tabular}

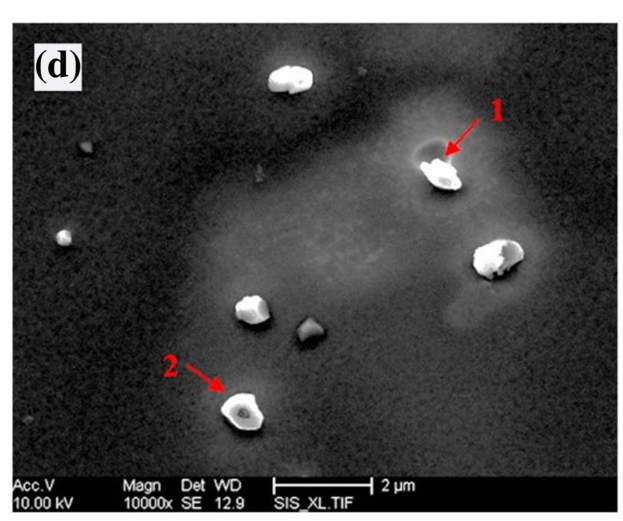

\begin{tabular}{ccc}
\hline $\begin{array}{c}\text { Element } \\
\text { wt } \%\end{array}$ & TiN & TiN/Mg $\mathrm{Mg}_{2}$ \\
\hline & 1 & 2 \\
\cline { 2 - 3 } $\mathrm{C} \mathrm{K}$ & 4.19 & 3.01 \\
$\mathrm{~N} \mathrm{~K}$ & 8.81 & 11.48 \\
$\mathrm{Mg} \mathrm{K}$ & & 8.76 \\
$\mathrm{MoL}$ & 7.15 & 4.41 \\
$\mathrm{Ti} \mathrm{K}$ & 30.72 & 45.09 \\
$\mathrm{Cr} \mathrm{K}$ & 18.81 & 15.04 \\
$\mathrm{Ni} \mathrm{K}$ & 26.91 & 10.14 \\
W M & 3.41 & 2.08 \\
Total & 100.00 & 100.00 \\
\hline
\end{tabular}

Fig. 19 Microchemical analysis of secondary phases in the upper layers of the walled structures of by quantification of EDS spectra (a) S Ni 6625, heat input: $0.30 \mathrm{~kJ} / \mathrm{mm}$, (b) S Ni $6625 \mathrm{AM} 1$, heat input: $0.31 \mathrm{~kJ} / \mathrm{mm}$, (c) S Ni $6625 \mathrm{AM}$, heat input: $0.37 \mathrm{~kJ} / \mathrm{mm}$ and (d) S Ni 6660 , heat input: $0.46 \mathrm{~kJ} / \mathrm{mm}$ 

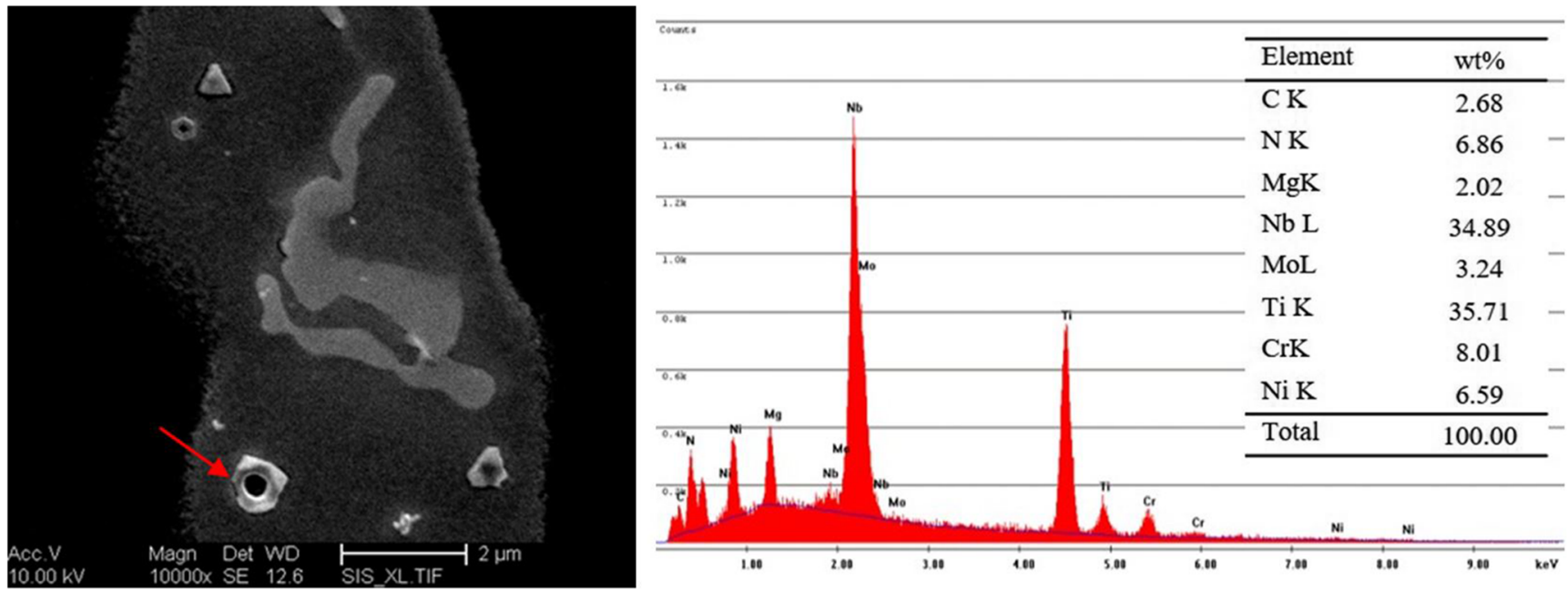

Fig. 20 Microchemical analysis of cubic TiN or TiN/NbC particles with Mg in weld metal of S Ni 6625 AM1 (heat input: $0.31 \mathrm{~kJ} / \mathrm{mm}$ ) by EDS spectra

Acknowledgements The present contribution is a part of the AiF project IGF-No. 20.616 B / DVS-No. 01.3145 of the German Research Association on Welding and Allied Processes (DVS). It was kindly supported by the AiF (German Federation of Industrial Research Associations) within the programme for promoting the Industrial Collective Research (IGF) of the Federal Ministry for Economic Affairs and Energy (BMWi), based on a decision by the German Bundestag. Sincere thanks are given for this support and to the representing companies actively involved in the project committee.

Funding Open Access funding enabled and organized by Projekt DEAL.

Open Access This article is licensed under a Creative Commons Attribution 4.0 International License, which permits use, sharing, adaptation, distribution and reproduction in any medium or format, as long as you give appropriate credit to the original author(s) and the source, provide a link to the Creative Commons licence, and indicate if changes were made. The images or other third party material in this article are included in the article's Creative Commons licence, unless indicated otherwise in a credit line to the material. If material is not included in the article's Creative Commons licence and your intended use is not permitted by statutory regulation or exceeds the permitted use, you will need to obtain permission directly from the copyright holder. To view a copy of this licence, visit http://creativecommons.org/licenses/by/4.0/.

\section{References}

1. Eiselstein HL, Tillack DJ (1991) The invention and definition of alloy 625 . Superalloys 718,625 and various derivatives, Edited by Edward A. Lmia, The Minerals, Metals \& Materials Society

2. DuPont JN (1996) Solidification of an alloy 625 weld overlay. MMTA 27:3612-3620. https://doi.org/10.1007/BF02595452

3. Shoemaker LE (2005) Alloy 625 and 725: trends in properties and applications. Superalloys 718, 625, 706 and Derivatives. Edited by E.A. Loria TMS (The Minerals, Metals \& Materials Society)

4. VDM® Alloy 625, Nicrofer 6020 hMo, Datenblatt Nr. 4118, Revision 03 (Mai 2018). https://www.vdm-metals.com/fileadmin/ user_upload/Downloads/Data_Sheets/Datenblatt_VDM_Alloy_ 625.pdf
5. DIN EN ISO 18274:2011-04: Schweißzusätze - Draht- und Bandelektroden, Massivdrähte und -stäbe zum Schmelzschweißen von Nickel und Nickellegierungen - Einteilung (ISO 18274:2010); Deutsche Fassung EN ISO 18274:2010. Beuth Verlag

6. DIN 17744:2020-06 - Entwurf: Nickel-Knetlegierungen mit Molybdän und Chrom - Zusammensetzung (Wrought nickel alloys with molybdenum and chromium - Chemical composition), 202006, Originalsprache Deutsch. Beuth Verlag

7. Hoffmeister W, Bartels M (2011) Technischer Stand beim Schweißplattieren - neueste Entwicklungen. Energie aus Abfall Band 8:371-393, TK Verlag Karl Thomé-Kozmiensky, Neuruppin

8. Yilmaz O, Ugla AA (2016) Shaped metal deposition technique in additive manufacturing: a review. J Eng Manuf 230(10):17811798. https://doi.org/10.1177/0954405416640181

9. Rodrigues TA, Duarte V, Miranda RM, Santos TG, Oliveira JP (2019) Current status and perspectives on wire and arc additive manufacturing (WAAM). Materials 12:1121. https://doi.org/10. 3390/ma12071121

10. Bergmann JP, Henckell P, Yarop A, Hildberbad J (2018) Grundlegende wissenschaftliche Konzepterstellung zu bestehenden Herausforderungen und Perspektiven für die Additive Fertigung mit Lichtbogen. DVS-Berichte Band 345, DVS Media GmbH, Düsseldorf, ISBN 978-3-96144-038-2

11. Varghese P, Vetrivendan E, Dash MK, Ningshen S, Kamaraj M, Mudali UK (2019) Weld overlay coating of Inconel 617 M on type $316 \mathrm{~L}$ stainless steel by cold metal transfer process. Surf Coat Technol 357:1004-1013. https://doi.org/10.1016/j.surfcoat.2018. 10.073

12. Solecka M, Kopia A, Radziszewska A, Rutkowski B (2018) Microstructure, microsegregation and nanohardness of CMT clad layers of Ni-base alloy on 16Mo3 steel. J Alloys Compd 751:8695. https://doi.org/10.1016/j.jallcom.2018.04.102

13. Silva CC, De Miranda HC, Motta MF, Farias JP, Afonso CRM, Ramirez AJ (2013) New insight on the solidification path of an alloy 625 weld overlay. J Mater Res Technol 2(3):228-237. https://doi.org/10.1016/j.jmrt.2013.02.008

14. Selvi S, Vishvaksenan A, \& Rajasekar E (2018) Cold metal transfer (CMT) technology - an overview. In Defence Technology (Vol. 14, issue 1, pp. 28-44). Elsevier ltd. https://doi.org/10.1016/j.dt.2017. 08.002

15. Xu F, Lv Y, Lui Y, Xu B, He P (2013) Effect of deposition strategy on the microstructure and mechanical properties of Inconel 625 
superalloy fabricated by pulsed plasma arc deposition. Mater Des 45:446-455. https://doi.org/10.1016/j.matdes.2012.07.013

16. Xu F, Lv Y, Liu Y, Shu F, He P, Xu B (2013) Microstructural evolution and mechanical properties of Inconel 625 alloy during pulsed plasma arc deposition process. J Mater Sci Technol 29(5): 480-488. https://doi.org/10.1016/j.jmst.2013.02.010

17. Cardozo EP, Ríos S, Ganguly S et al (2018) Assessment of the effect of different forms of Inconel 625 alloy feedstock in plasma transferred arc (PTA) additive manufacturing. Int J Adv Manuf Technol 98:1695-1705. https://doi.org/10.1007/s00170-018-2340$\mathrm{z}$

18. Wang JF, Xizhang C, Chuanchu S (2019) Microstructure and mechanical properties of Inconel 625 fabricated by wire-arc additive manufacturing. Surf Coat Technol 374:116-123. https://doi.org/10. 1016/j.surfcoat.2019.05.079

19. Wang JF, Sun QJ, Wang H, Liu JP, Feng JC (2016) Effect of location on microstructure and mechanical properties of additive layer manufactured Inconel 625 using gas tungsten arc welding. Mater Sci Eng: A 676:395-405. https://doi.org/10.1016/j.msea. 2016.09.015

20. Tanvir ANM, Ahsan MRU, Ji C et al (2019) Heat treatment effects on Inconel 625 components fabricated by wire + arc additive manufacturing (WAAM) - part 1: microstructural characterization. Int J Adv Manuf Technol 103:3785-3798. https://doi.org/10.1007/ s00170-019-03828-6

21. Tanvir ANM, Ahsan MRU, Seo G et al (2020) Heat treatment effects on Inconel 625 components fabricated by wire + arc additively manufacturing (WAAM) - part 2 : mechanical properties. Int J Adv Manuf Technol 110:1709-1721. https://doi.org/10.1007/ s00170-020-05980-w

22. Jiang Q, Zhang P, Yu Z, Shi H, Li S, Wu D, Yan H, Ye X, Chen J (2021) Microstructure and mechanical properties of thick-walled Inconel 625 alloy manufactured by wire arc additive manufacture with different torch paths. Adv Eng Mater 23:2000728. https://doi. org/10.1002/adem.202000728

23. Wang JF, Xizhang C (2019) Investigation on the microstructure and corrosion properties of Inconel 625 alloy fabricated by wire arc additive manufacturing. Mater Res Express 6(10):106568. https://doi.org/10.1088/2053-1591/AB39F6

24. Mookara RK, Seman S, Jayaganthan R et al (2021) Influence of droplet transfer behaviour on the microstructure, mechanical properties and corrosion resistance of wire arc additively manufactured Inconel (IN) 625 components. Weld World. https://doi.org/10. 1007/s40194-020-01043-6

25. Kiser SD, Lippold JC, DuPont JN (2009) Welding metallurgy and weldability of nickel-base alloys. Verlag: John Wiley \& Sons, ISBN-13: 9780470500217

26. Wittig B, Zinke M, Jüttner S, Keil D (2017) Experimental simulation of dissimilar weld metal of high manganese steels by arc melting technique. Weld World 61:249-256. https://doi.org/10.1007/ s40194-017-0427-z

27. DIN EN ISO 4288:1998-04: Geometrische Produktspezifiaktion (GPS) - Oberflächenbeschaffenheit: Tastschnittverfahren Regeln und Verfahren für die Beurteilung der Oberflächenbeschaffenheit (ISO 4288:1996); Deutsche Fassung. Beuth Verlag
28. DIN EN ISO 17636-1:2013-05: Zerstörungsfreie Prüfung von Schweißverbindungen - Durchstrahlungsprüfung, Teil 1: Röntgen- und Gammastrahlungstechniken mit Filmen (ISO 17636-1:2013); Deutsche Fassung. Beuth Verlag

29. Floreen S, Fuchs GE, Yang WJ (1994) The Metallurgy of Alloy 625, Superalloys 718, 625, 706 and Various Derivates, ed. E. A. Loria, The Minerals, Metals \& Materials Society: 13-37

30. Valencia JJ, Spirko V, Schmees R (1997) Sintering effect on the microstructure and mechanical properties of alloy 718 processed by powder injection molding, Superalloys 718, 625, 706 and Various Derivates, ed. E. A. Loria, The Minerals, Metals \& Materials Society: 753-762

31. Cieslak MJ, Knorovsky GA, Headley TJ, Romig AD (1986) The use of new PHACOMB in understanding the solidification microstructure of nickel base alloy weld metal. Met Trans A 12(A):21072116

32. Rizzo FJ, Justus SB (1994) PM alloy $625 \mathrm{M}$ - a high strength modification of alloy 625 , superalloys $718,625,706$ and various derivates, ed. E. A. Loria, The Minerals, Metals \& Materials Society: 903-911.

33. Rizzo FJ (1994) Strengthening precipitates in argon atomized PM alloy 625 , superalloys $718,625,706$ and various derivates, ed. E. A. Loria, The Minerals, Metals \& Materials Society: 913-922

34. Sundararaman M, Kishore R, Mukhopadhyay P (1994) Some aspects on the heterogeneous precipitation of the metastable $\gamma$ " phase in alloy 625, M. Sundararaman, Superalloys 718, 625, 706 and Various Derivates, ed. E. A. Loria, The Minerals, Metals \& Materials Society: 405-418

35. Hauck G (1989) Qualitätsanforderungen an Drahtelektroden beim Schutzgasschweißen mit Robotern. DVS-Berichte 118:71-76 DVS-Verlag Düsseldorf

36. Baas P (1990) Störungsfreier Drahtvorschub - eine Voraussetzung zum wirtschaftlichen MIG-/MAG-Schweißen. DVS-Berichte 131: 167-170 DVS-Verlag Düsseldorf

37. Tammi V, Dios M (1989) Reibkraftmessung in SchutzgasSchweißbrennern - die optimale Drahtförderung. Sonderdruck A. Binzel, Gießen

38. Witzel J (2015) Qualifizierung des Laserstrahl-Auftragschweißens zur generativen Fertigung von Luftfahrtkomponenten, ShakerVerlag, Acchen

39. Ruiz-Vela JI, Montes-Rodríguez JJ, Rodríguez-Morales E, Toscana-Giles JA (2019) Effect of cold metal transfer and gas tungsten arc welding processes on the metallurgical and mechanical properties of Inconel ${ }^{\circledR} 625$ weldings. Weld World 63:459-479. https://doi.org/10.1007/s40194-018-0661-z

40. Silva CC, De Albuquerque VHC, Miná EM, Moura EP, Tavares JMRS (2018) Mechanical properties and microstructural characterization of aged nickel-based alloy 625 weld metal. Metall and Mat Trans A 49:1653-1673. https://doi.org/10.1007/ s11661-018-4526-2

Publisher's note Springer Nature remains neutral with regard to jurisdictional claims in published maps and institutional affiliations. 